\title{
GEOLOGY OF TAMA COUNTY BY
}

\author{
T. E. SAVAGE
}




\title{
GEOLOGY OF TAMA COUNTY.
}

\author{
BY T. E. SAVAGE.
}

\section{CONTENTS.}

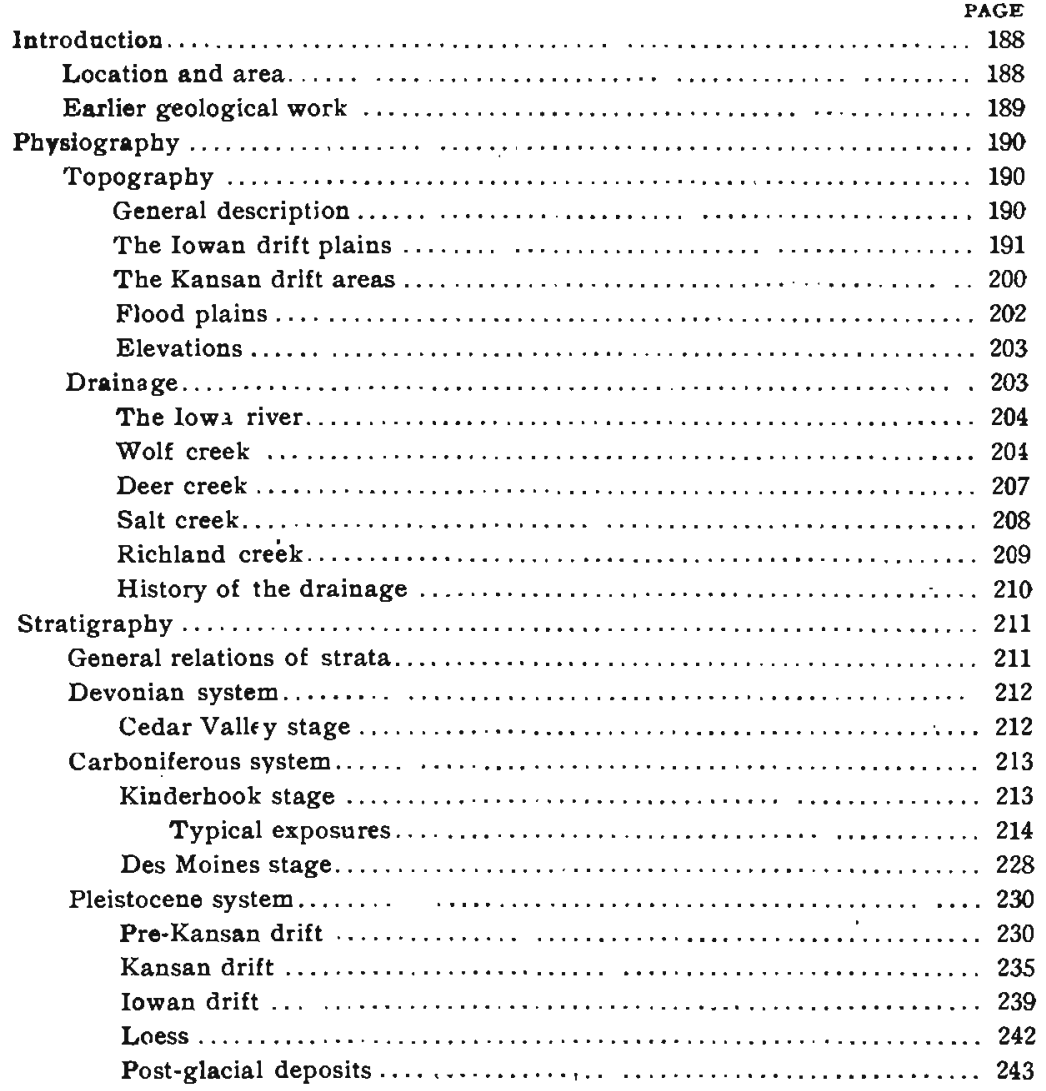




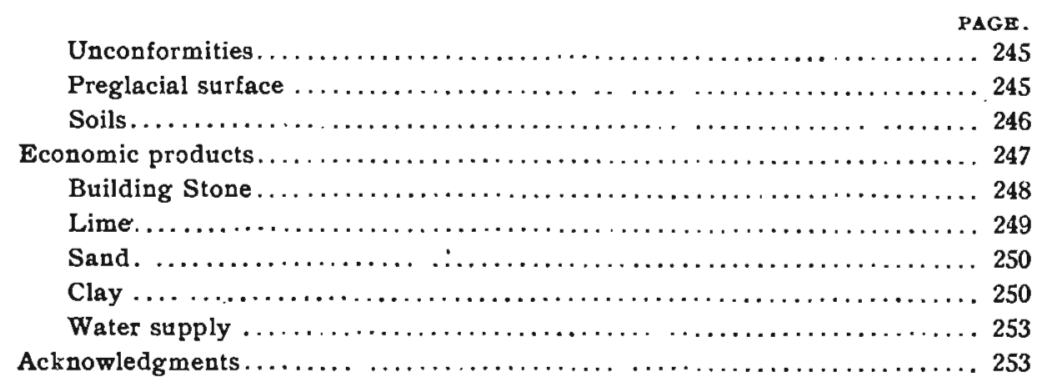

\section{INTRODUCTION.}

\section{LOCATION AND AREA.}

Tama county was named after the Musquakee Indian-Tai-amah.* It embraces a beautiful area situated in the east-central portion of Iowa. It lies in the middle row of counties extending: east and west and in the second tier to the east of the center of the state. The counties of Grundy and Black Hawk border it on the north and Benton lies on the east. Poweshiek county touches it on the south and Marshall and Grundy form its western boundary.

Tama county embraces an area inclided by the United States land survey in the townships 82 to 86 north and ranges 13 to 16 west of the fifth principal meridian. It is a rectangle in form, thirty miles in length north and south and twenty-four miles in width. It comprises twenty congressional townships which give it an area of 720 square miles. One of these congressional townships, that in which the the towns of Tama and Toledo are situuated, has been divided into two civil townships. Sections 1 to 24 inclusive form the civil township of Toledo, while the remaining sections, 25 to 36 , constitute the township of Tama.

A part of this fortunate area lies within the limits of the Iowan drift plain, and furnishes to the agriculturalist a soil unsurpassed in its depth and productiveness by any portion of our fertile state. The southern part of the county is richer in the wealth of forest growth and woodland beauty. The steeper hill slopes and broad valleys where less suitable for constant tillage afford for

- MeGeo: Eleventh Annual Report U. S. Geol. Surq., p. 318. 
grazing purposes conditons but seldom: equaled. To the earlier settlers of Iowa this region must have appeared as a happy land in which to found a home. The well wooded southern portion would appeal to the pioneer who had migrated from the timber districts of the east, and would assure to him and his posterity the possibility of an abundance of fuel with which to meet the rigors of western winters, while close at hand stretched the treeless prairie of the Iowan drift plain waiting only for the plow and the seed to reward the husbandman with bountiful harvests. Although there are but few exposures of indurated rocks over this region, yet to the geologist the county presents features of more than usual interest for the reason that the soils of the area have been derived from two different ice invasions, separated from each other by an exceedingly long interval of time; while the well borings and excavations reveal the presence of a third drift sheet underlying and very much older than either of the other two.

\section{EARLIER GEOLOGICAL WORK.}

In his description of the range of the Carboniferous limestone in Iowa, published in $1852, \mathrm{D}$. D. Owen mentions the exposures along the Iowa river on the western border of Tama county. He also describes the symmetrical mound-like form of some of the outliers of the limestone in this region, and figures one which doubtless represents what is known locally as the Devil's Anvil, near the Tama and Marshall county line. Professor Owen included the southwest corner of the corunty within the limits of the coal fields of the state.*

In his report on the Geology of Iowa in 1858, Professor James Hall notices the meagreness of the rock exposures over the surface of Tama county, and refers to one or two outcrops which he found near Butlerville, or Indian-town. In this connection he pays a tribute to the excellent quality of the soil over the particular region under consideration. $\dagger$

Professor C. A. White, State Geologist of Iowa from 1866-1869, devotes two or three pages in his report to a description of the rocks and the quarries which are found near Le Grand. The greater part of this description might with almost equal propriety

*Owen: Geol, Surr. of Wisconsin, Iowa and Minnesota, pp. 28, 98, 101 and 102.

+Hall: Geol. of Iowa, Vol. 1, pt. 1, pp. 260-2088. 
be applied to the exposures in Tama county about one mile farther down the Iowa river.*

Tama county is included within the area of northwestern Iowa, the Pleistocene history of which has been so beautifully written by W J MoGee. $\dagger \mathrm{He}$ refers to the exposures of the Kinderhook limestone along the Iowa river between Marshall and Tama, and mentions the wide character of the flood plain of the river as it meanders through the county. He speaks of the deep covering of loess over the hills west of Tama City and gives a few sections or wells within the area.

In $1898 \mathrm{Mr}$. H. R. Mosnat published a report on the artesian wells of the Belle Plaine area, in which area the southeastern portion of Tama county is included. Mr. Mosnat gives a general description of the deposits associated with the water bearing bed and mentions a number of wells put down within the borders of the district under discussion. +

Two years ago the present writer published a short paper on an exposure of pre-Kansan drift in Tama countw. $\$$

\section{PHYSIOGRAPHY.}

TOPOGRAPHY.

General Description.-Tama county embraces a region of extensive level or undulating prairies unbroken by branch or gully; a region also of well matured drainage where deep dissecting ravines are bordered by high loess covered hills and abrupt slopes; a region where the smooth unsculptured plain of the Iowan drift gives place to the treuched and furrowed surface of the Kansan. The line of surface contact along which these two drift sheets meet is indicated by a border of irregular hills; the drift of which they are largely composed is of Kansan age while the caps of sand or loess were probably deposited during the time the Iowan ice prevailed and stood at its maximum southward extension.

\footnotetext{
-White: Geol. of Iowa, Vol. I1, pp. 312-314.

tMeGee: Pleistocene History of Northeastern Iowa, Eleventh Ann. Rep. U. S. Geol. Surv. pp. $409,428,432,470$ and $528,1889-1890$

$\ddagger$ Mosnat: Iowa Geol. Surv., Vol. IV, pp. 523-562.

SSavage: Proc. Iowa Acad. of Sciences, Vol. VIII, pp. 275-i78.
} 
- In some places where a lobe of the Iowan ice advanced farther south than the main sheet the mantle of drift which was left is so thin that the characteristic features of the Iowan plain were not impressed upon the area. Here we have a mixed or hybrid topography where the subdued hills of Kansan drift, in many cases covered with beds of sand or loess twenty to twenty-five feet in thickness, look down upon valleys choked and filled with glacial debris in which are found drift and granite bowlders of the Iowan age.

Besides the above mentioned topographic features the very wide flood plains through which the most of the larger streams of the county flow, present their characteristio level type of surface.

The Iowan Drift Plains. - A sinuous line of hills which marks the southern margin of the Iowan drift sheet enters on the west side of Tama county about one and one-half miles north of the Iowa river, near the southwest corner of section 30 , Carlton township. From this point it trends southeast for about one mile, to the eastern part of section 31, then passes north for two and onehalf miles. Near the southeast corner of section 18 these low

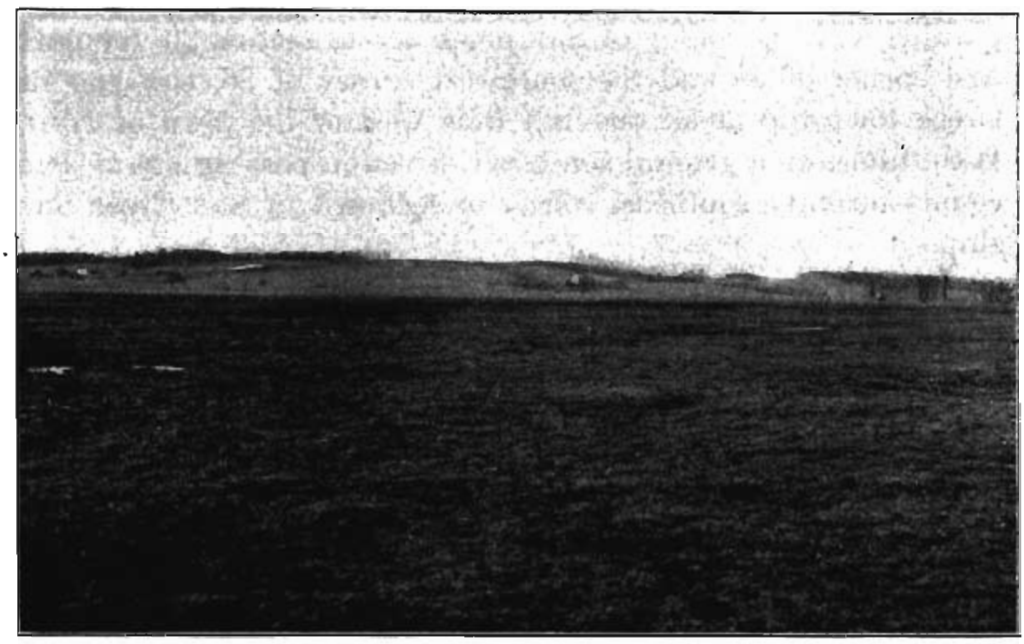

Fig. 19. Margin of the loess Kansan area in Carlton towaship, showing the ridges which mark the border of the Iowan drift plain. 
ridges which constitute the Iowan moraine trend eastward, reach- • ing Deer creek about one-fourth of a mile south of the corporation limits of the town of Garwin. From this point they trend towards the northeast, across Howard township, entering Carroll township near the southwest corner of section 6 . Thence they continue so nearly eastward that where they leave section 10 , four. miles further east, they have scarcely passed one-mile to the south. The border of hills now bends to the southeast and continues: parallel with the channel of Salt creek passing across section 11 and the southwest corner of section 12, then drops southward for over a mile, leaving the township about one-fourth of a mile south of the northeast corner of section 24. For a distance of one and threefourths miles it continues southeast. It then bends west for one mile along the north side of section 31 ; then turning to the southeast it crosses section 31 and the southwest corner of section 32, entering York township about the middle of the north side of section 5. Continuing southeast one-half mile and then east for three quarters, it bends southward for a distance of two miles and one-half. It then trends southeast for about one mile; bending south one mile further it passes nearly due east for threequarters of a mile and then bends to the sontheast, continuing parallel with the valley of Salt creek across section 26, the northeast corner of 35 and the southwest corner of 36, entering Salt Creek township about one-half mile west of the town of Irving. It continues in a general southeast direction passing out of Tama county near the southeast corner of section 1 of Salt Creek township.

All of that portion which lies to the north of the line traced above, embracing about one-half of the area of the county, is a part of the extensive plain of Iowan drift which stretches away to the northward beyond the limits of the state. This surface is generally level, or but slightly undulating. The drainage is but imperfectly developed over most of the area. The broad, shallow channels along which the excess of water is discharged head in seepy sloughs or swales, and the most of the smaller streams have scarcely cut a definite bed in which their waters are confined.

The northern portion of the county is crossed by Wolf creek. This is a stream of considerable size which has cut its channel to 
a depth of thirty or forty feet into the Kansan drift. It flows in an ancient valley which was excavated before the invasion of the Iowan glaciers. The amount of drift materials that was carried by the Iowan ice was not sufficient to completely bury the old channel, and so, when the ice retreated, the waters once more became established in this pre-Iowan bed. Owing to the very thin mantle of Iowan drift which was left over this region the waters of Wolf creek and its tributaries have been able to remove the greater part of the Iowan covering from the immediately adjacent lands. Such erosion has occurred whenever a slope of a few degrees has been developed, exposing along the roadsides and in the banks of the ravines the older sheet of Kansan till.

There is thuss a belt, two to four miles in width, bordering Wolf creek, which lies within the area of the Iowan drift but which presents the bold forms of water sculpture so characteristic of the Kansan plain. The physical features which this strip pre- sents are but a forecast of the fate which will eventually overtake all of the level prairie country as the drainage becomes more and more perfected, unless there intervenes some counteracting force to check the slow but ceaseless work of the stream erosion.

From: the main sheet of Iowan drift above described a tongue shaped lobe having an average width of about six miles, extends southward for a distance of eight or nine miles, reaching one mile below the city of Toledo and within two miles of the Iowa river. This extension may be called the Toledo lobe of the Iowan drift. It is bordered on the west, from the point where it leaves the main lowan drift sheet about the middle of the south half of section 14 of Carlton township down to near the middle of section 21 of Toledo township, by the hills which form the west bank of the valley of Deer creek. From the latter point the irregular ridges which mark the margin of the lobe trend to the southeast for one-half mile and then eastward, continuing in an undulating line near the north side of sections 27, 26 and 25 of the township of Tama. They enter Otter Creek township not far from the southwest corner of section 19. From this point they trend in a northeasterly direction across the southern portion of section 19 and bending further to the north they cross the northwest corner of section 20 . Otter creek passes throngh a gap in these hills near the southwest 
corner of section 17. From here the ridges extend in a general northerly direction, bending alternately eastward and westward, near the west side of sections 17, 8 and 5. They enter Carroll township near the southeast corner of section 31. Continuing northward with a slight inclination toward the west for a distance of five miles, they merge into the morainic hills of the proper Iowan drift plain near the southwest corner of section 6 .

This Toledo lobe covers the greater portion of Howard township, a small corner of Carlton, a little more than the east half of the township of Toledo and a narrow strip from the west side of the townships of Otter Creek and Carroll. It is about four and one-half miles in width at the southern extremity and nearly eight miles across at the north where it leaves the main sheet. It embraces an area of over 31,000 acres.

Over the southern portion of this lobe the surface is that of a billowy prairie. The elerations seldom exceed swenty feet above the broad channels of the streams. A thin covering of Iowan drift cecurs over the lower lands and in places is found even on the tops of the subdued hills. The drift is of the typical Iowan character. It is yellowish brown in color. The iron which it contains is not fully oxidized and the calcareous matter is not leached from the surface. It carries but few pebbles or small bowlders. as compared with the Kansan and of these there is but a small percentage of the dark colored trap or greenstones.

Over this region the Iowan drift is usually concealed beneath a covering of loess which varies from a foot or two to several feet in thickness. Such a loess covered bed of Iowan drift is well exposed along the roadside between sections 18 and 19 of Otter Creek township, and again about the middle of the line which separates sections 23 and 26 of Howard township. The presence of loess overlying Iowan drift is not unique over the state but this is not its usual mode of occurrence. In central and southern Iowa the deeper beds of loess are found covering Kansan drift at no great distance from the Iowan border. It seems probable that then as now loess materials were deposited on the leeward side of obstructions to dust-laden currents of air, or where in the path of such winds the soil was covered with vegetation which would serve to catch and retain the dust particles that fell upon it. How- 
ever, the distribution of loess orer this portion of the state would indicate that during the time when the Iowan ice prevailed, the conditions were exceptionally favorable for its deposition and that probably the source of much of the material might have been the super-glacial silt from the Iowan ice sheet itself.

Very often the deposits of Iowan drift are found in the valleys while till of Kansan age composes the hills, emerging at the surface along the upper part of the slopes. Examples of hills with Kansan drift exposed at the top and having Iowan materials flanking the base may be seen in the northern part of section 35 of Howard township, and along the middle line of section 21 of the same township.

The Iowan ice which pushed down over this area carried quite a large number of light-colored, granite bowlders. These bowlders are usually from four to eight feet in diameter but individuals ten to twelve feet in length are not rare, while one specimen was seen with a long diameter of about thirty feet. Bowlder strewn fields, some of the rocks of large size, may be seen about eighty rods south of the Toledo and Cedar Rapids road, one in the eastern part of section 23, and another in the westeru part of section 24 of Toledo township. Occasional bowlders dot the surface along the courses of streams over all of this region. They are seldom found on the higher points but seem to have been left during the process of the melting of the ice that carried them, either on the lower flanks of the slopes or along the beds of the streams.

The topographic features of an area across the middle portion of this lobe are bolder. The tops of the hills stand in many places forty to fifty feet above the valleys. The contours are quite sharp and the slopes are steep. The irregular character of these sand or loess capped hills resembles very closely the ridges which are found around the margin of the Iowan drift plain. Even here, however, the stream channels cholsed and clogged with aqueoglacial debris, the accurrence of Iowan drift near the base of the hills, and the presence of large, light-colored, granite bowlders along the valleys, bear indubitable testimony to the former presence of the Iowan ice sheet. The axes of these hills are composed of Kansan drift, but their tops are usually covered with sand or 


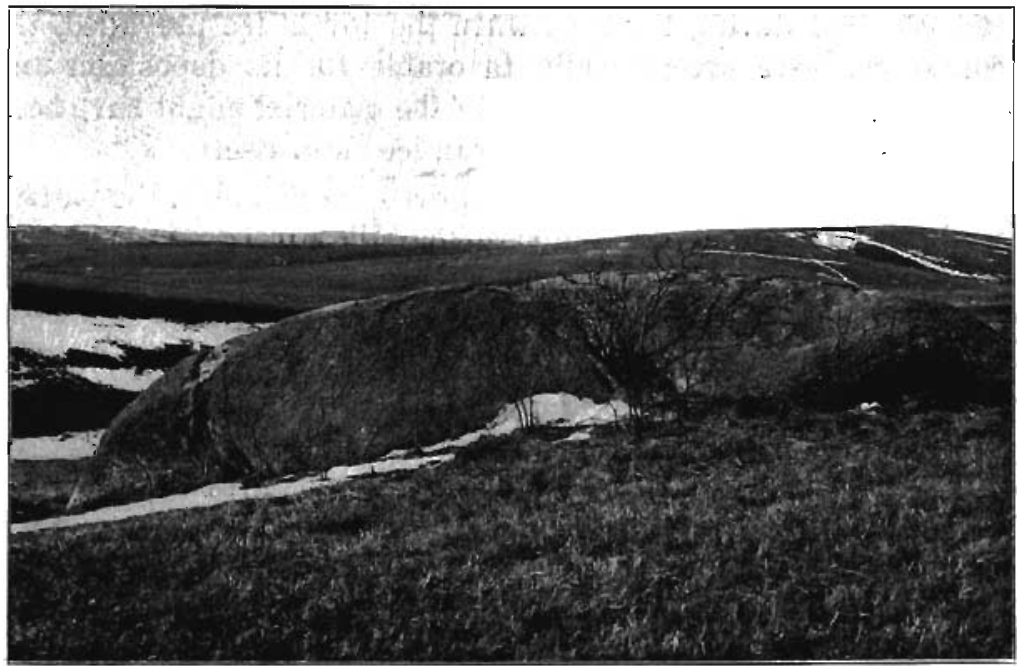

Fig. 20. View showing the topography of the Toledo lobe in the edge of the hills which cross the central portion of this extension of Iowan drift; showing also a large bowlder of Iowan age stranded near the top of one of the hills. The Iowan bowlders are nsually found only at or near the foot of the hills. About one and one-half mile northwest of the county poor farm, Toledo townshy.

with loess, often to a depth of from fifteen to thirty feet. A short distance sonth of the Monticello church in section 33 of Howard township, the road has been cut through a bank of loess, exposing a depth of about fifteen feet, while in the valley a short distance away there may be seen a bed of Iowan drift. The loess at this place is very fossiliferous, containing numerous individuals of species of Polygyra, Succinea, Pupa and other common genera. Examples of sand covered hills over this area are numerous, but typical places have been already cited.

The peculiar topography of the Toledo lobe, the presence of loess overlying the Iowan drift, together with the vely scant amount of material that the Iowan ice sheet left over its surface would seem to indicate an unusual episode in the history of the Iowan ice action. The phenomena which it presents lend themselves to the following interpretation. During the early stages of the extension of the Iowan glacier a narrow lobe of ice was pushed southward beyond the main body over the deeply eroded Kansan 
surface, covering the area outlined as the Toledo lobe. For some reason the pressure from behind soon became insufficient to keep up the movement over this lobe and the ice which covered the region became dead, and gradually melted where it came to rest. As the glacier moved slowly over the old Kansan surface, the stones which were held fast along the bottom of the ice would form instruments of attrition of the most effective kind. The materials on the tops of the hills, even though frozen solid, could not but yield rapidly to this grinding action of the ice. The debris worn off from the higher points would be pushed cyer into. the valleys to the leeward of the advancing ice sheet. In this manner the surface inequalities would gradually be reduced both by the constant wearing down of the greater elevations, and by the no less constant filling of the valleys with the materials removed from the tops of the hills. Owing to the short period during which the flow of ice continued over this surface, the tops of the Kansan hills were not subjected to the powerful abrading action of great masses of moving ice for so long a period as were those where the flow continued for the whole time during which the Iowan ice prevailed. As a consequence the pre-Iowan surface here was not planed down to the same extent as it was over the area covered by the main sheet of the Iowan drift.

,The generally smooth character of the Iowan drift surface is probably due more to the leveling action of thick masses of ice moving over the region than to the amount of materials transported from great distances which the ice left as it retreated. The Iowan ice did not generally carry such a large amount of drift and debris as the Kansan, as is witnessed by the comparatively thin sheet of materials which is usually found covering the Kansan drift over the main Iowan plain. However, it is probable that the small quantity of ice which melted over this lobe would be one good and sufficient reason for the unusually thin mantle of Iowan materials that is found over its surface.

- The cause or causes which resulted in the early cessation of the flow of ice over this lobe did not produce their full effect at once. The movement probably ceased quite suddenly over the southern half of the area, but its withdrawal from the northern portion was accomplished much more slowly and at a much less 
uniform rate. A halting in the retreat of the ice near the central portion of the lobe, its line of lower limit receding but very slowly through a long period of time, would result in the accumulation around its margin of deposits of sand and loess by the overwash of materials liberated from the melting ice and by the action of winds sweeping over the surface of the ice sheet and laying down their load to the leeward of its margin.

As a consequence of such deposition the Kansan hills immediately around the border, which had been leveled down to some -extent by the ice moving over them, were built up to a height twenty to thirty feet above the more elevated points in the southern partion of the lobe. During this time, also, much of the fine-grained loess materials gathered up by the winds would be carried out some distance beyond the margin of the ice, and thus the southern portion of the lobe would receive a mantle of loess above the Iowan drift which had been previously deposited over the area. When the ice melted there was left the helt of sand or lcess crowned hills, one-half mile to a mile in width, which forms so conspicuous a feature across the north-central portion of the lobe.

Some time before the entire withdrawal of the Iowan glacier from the county, the flow of ice ceased over the northern portion of the lobe, the margin retreated to about the same distance southward as that of the main body of the Iowan ice. Along this border a new series of ridges was formed, but the width of this belt is less than that of the one which crosses the central portion of the lobe. The individual ridges are also lower and less conspicuous. Pleasant Hill church, situated about the middle of the south side of section 2 of Howard tawnship, is located on one of the ridges of this moraine.

After the retreat of the ice from the 'Toledo lobe and probably before the entire withdrawal of the Iowan sheet from this portion of the state, a deposit of loess was laid down in places over the northern portion of the area under consideration.

With this deposit and the retreat of the ice, the stage of the Iowan ice invasion was closed. From that time, so long ago when measured in years yet so recent from a geological point of view, the forces of weathering and erosion have modified but 
slightly the topographio forms of its surface, adding only the last touches to the features which the region presents today.

A third body of Iowan drift oceurs in Tama county on the south side of the river. This area is an extension eastward of the Iowan drift plain from Marshall county. Its northern margin follows quite closely the Iowa river bluff for a distance of over two miles, reaching within one-half mile of the town's of Butlerville and Montour. From here it stretches away to the southeast across sections 33 and 34 of Indian Village township and passing across sections 2 and 12 of the township of Highland it extends eastward about one and one-half miles into the township of Columbia. The southern margin of this extension follows westward near the north side of Richland creek to about section 23 of Highland township where this body of lowan ice merges into a southern area which is bounded on the nmth by the valley of Richland creek and which extends eastward to the southeast corner of Columbia township. This area of Iowan drift stretches away southward into the county of Poweshiek. It is probable that the body of Iowan drift south of the rirer was a continuous area and that the seeming division which appears along Richland creek is due to the removal of all traces of the Iowan deposits by the erosion of that oreek and its affluents in this particular region.

The topography of this Iowan drift plain is somewnat similar to that of the southern portion of the Toledo lobe. The hills are subdued but not effaced. The stream channels are obstructed but not filled to such an extent as to prevent effective drainage. There are no great surface inequalities over the area, the tops of the hills usually standing not more than twenty or twentyfive feet above the valleys. There are fewer bowlders left over this region than occur over the Iowan areas north of the river. However, a few individuals of large size may be seen about the middle of the line which separates sections 26 and 27 of Highland township and others again near the southwest corner of section 29 and the southeast corner of section 30 of Columbia. It would seem as if the Iowan ice sheet which spread orer this portion of the county must have been exceedingly thin; that its flow continued but a very short time, and that it carried but a 
scanty amount of detritus of any kind. The hill slopes in numbers of places expose the oxidized Kansan drift overlain with a mantle of loess; almost the whole of this area being loess covered. The word mantle is an appropriate term as applied to the loess. Wherever it occurs in the county it forms ai cloak or blanket, usually thin, which conforms in almost every case to the preexisting inequalities of the surface over which it lies. Good exposures of typical Iowan drift are here exceedingly rare. However, the hills are not so high, the contours are not so sharp and the stream channels are not so open nor so deep as they are over the typical areas of Kansan drift. The occasional large bowlders of gray granite which sentinel the drainage courses are added witnesses to a transient visit of the Iowan ice.

The Kansan Drift Areas.-- On the north side of the Iowa river and to the west of Salt creek a body of Kansan drift extends northward to the margin of the Iowan drift plain. The area is nearly cut in two by the southward extension of the Toledo lobe above described. The topography of this region is exceedingly

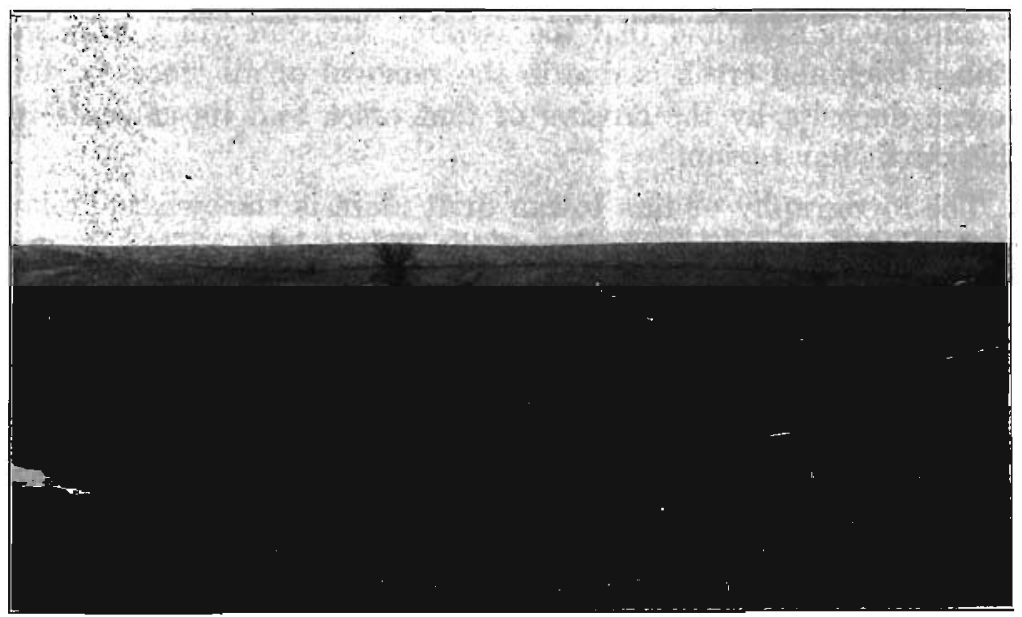

Fyg. 21. View showing the topography of the loess Kansan area near the southern portion of Tama county:

irregular and its forms have been molded by the action of long continued erosion. The surface is dissected in all directions 
with an intricate system of drainage channels. The numerous streams, each: with its series of pinnately branching tributaries, have carved the entire region into alternating ridges and ravines. The uplands are narrow. The hills are high. Their tops' are crawned with a deep deposit of loess which heightens the inequalities of the surface. The slopes are steep as is usually the oase when deeply loess covered districts are subjected to strong: erosion. The smaller stream channels are sharply angular and the forces of erosion are energetic at the present time. From the west portion of this area, a narrow strip of Kansan drift, varying from forty to eighty rods in width, extends northward along the west bluff of the valley of Deer creek for a distance of a bout five miles. This peculiar belt is typical Kansan in character and for some unknown reason was avoided by the Iowan ice which came down on either side.

The hills which form the north bluff of the Iowa river valley are in many places covered with sand. These deposits are probably in the nature of dunes, the materials having been gathered up by the winds as they swept down the broad valley of the river. Examples of such hills occur along the river bluff a few miles east of Chelsea and again a short distance east of the town of Gladstone. In the western part of the county, the sand hills are replaced by loess capped bluffs. Such deposits appear about one and one-half miles east of Tama. At this place in a loess bank about twenty feet in depth Mr: Bentley obtains clay for the manufacture of brick and tile. Several miles farther up the river, along the south side of section 13 of Indian Village township, beds of very fossiliferous loess crown the bluffs which overlook the broad valley opposite the town of Montour.

On the south side of the river the Kansan drift is also overlain by a blanket of loess. Deposits of loess and till of Kansan age constitute the superficial materials over all the the southern portion of the county east of the Iowan area above described. The topography of this region resembles in a general way that of the Kansan drift area lying to the north of the river. Rounded, irregular knolls and open, sharp ravines alternate in almost endless: succession. The land features are mature and long; continued 
erosion has intersected the region with such a network of stream channels that the level upland areas are few, scattered and of small extent. The beds of Ioess are not quite so deep as on the north side of the river, but here also frequent deposits of loess andl sand cap the bluffs which form the south wall of the valley of the Iowa river.

Stream Flood Plains.-The valley of the Iowa river which passes diagonally across the southern portion of the county has an average width of more than two miles. Over this broad plain the river meanders from side to side in a series of broad, swinging curves. Cut-offs have been made in the past and ox-bow lakes occur at a number of places over the plain. A good example of such a curved lake may be seen a short distance above the town of Montour, and several others occur in Salt Creek township below the town of Chelsea. The river swamp is not perfectly drained and shallow marshes are not infrequent over the area at some distance from the river. The bed of the river is but twelve or fifteen feet below the level of the river swamp so that the whole plain is subject to inundation during periods of great flood, such as occurred in the summer of 1902.

The river is bordered throughout almost its entire distance in the county by steep bluffs forty to seventy feet in height. These hills are usually compased of Kansan till capped with a bed of loess or sand. Ledges of indurated rock outcrop in the banks only for a short distance in the western part of its course after it enters from Marshall county.

Each of the larger creeks flows in a broad alluvium covered valley one-half mile to a mile in width, which seems entirely out of proportion to the size of the stream which it accommodates. These valleys, like that of the Iowa river, were probably excavated in preglacial times. They are guarded by hills of drift whose tops usually overlook the plain from a height of forty or fifty feet.

The following: elevations taken from Gannett's Dictionary of Altitudes in the United States will give the height above sea level of some of the principal places in the county. 


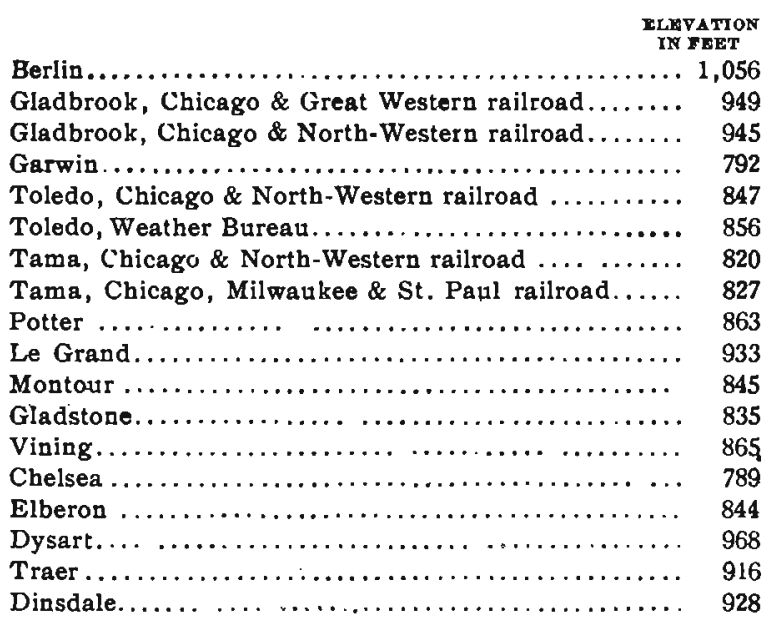

It will be noticed in the above table that the most of the places mentioned from the south and west sides of the county are situated on low bottoms, as the flood plain of the Iowa river and of Deer creek; while most of those given from the north ancl eastern portion of the area are located on the uplands of the Iowan drift plain.

\section{DRAINAGE.}

From a consideration of the table of elevations it will be seen that the highest portion of the county is in the northwest corner and the lowest part is in the southeast. The difference in the altitude between these points is 267 feet. The surface over the northern portion of the county slopes gently towards the east while in the central and southern portions it is inclined towards the south as well as east. As would be expected the streams of the area follow the direction of the slope, conforming in a general way to the normal direction of flow of the rivers of eastern Iowa.

The surface of the county is fairly well drained, even over the more level portions of the Iowan drift plain. The streams belong to two principal drainage systems, the Cedar river and the Iowa. The divide passes east andi west across the central portion of Spring Creek township, dipping a little south of the 
middle of Crystal and thence acrass nearly the central portion of the townships of Perry and Olark. The town of Dystrat stands on the south edge of this watershed. . Cedar river receivives all of the excess: of water which falls up.on the surface north of the divide, draining almost one-third of the area of the county. The Iowa river is the master stream of all of the central and southern portion of the region under consideration.

The Iowa River.- The Iowa river enters Tama county from Marshall near the northwest corner of section 6 of Indian Village township. It holds a general southeasterly course winding diagonally across Indian Village township and the township of Tama, the northeast corner of Columbia, the north half of Richland and the central and southern portion of Salt Creek. It leaves the county about the middle of the east side of section 36 of the latter township. Following all of its numerous curves and zigzag windings, the waters of the Jowa river flow for a distance of about fifty-five miles within Tama county. From the north it receives tribute from Sugar, Deer, Otter and Salt creeks, while Raven, Bennett and Richland creeks flow into it from the south.

For the first six miles after entering the county the curves of the river have deflected the current against the opposing banks, cutting them away at intervals so far as to expose ledges of Kinderhook limestone in the bluffs which border the valley. During all of the rest of its course the river meanders in a broad valley which in preglacial times was excavated in the Lower Carboniferous limestone. Wells which have been bored over this broad flood plain indicate that the preglacial channel was cut down 175-20 feet below the bed of the present river. This ancient channel was filled with drift brought down by the pre-Kansan and Kansan ice. The present river has cut a valley into the Kansan drift two miles in width, to a depth of forty to seventy feet below the general level of the uplands. The width of the preg]acial valley has not been determined as in no place along this part of its course have the bordering ledges of rock been exposed.

Wolf Creek. - Of the streams of the county, Wolf creek is seeond in size ondy to the Iowa rixer. It is the major stream of all of the northern portion of the county. It rises in the gullies and 


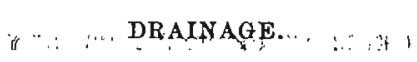

sharp trenches which have been graven into the surface of the eastern portion of Marshall county. It passes across the northern part of the townships of Spring Creek, Crystal axd Perry. Thence bending to the northeast, it crosses the southeast corner of Buckingham and continues eastward near the central portion of Genesea township. It leaves the countr about the middle of the east side of the latter township, a short distance before it makes the more abrupt turn northward to meet the Cedar river. That part of its basin which is included in Tama county embraces an area of about 225 square miles. This stream follows along very close to the south side of its basin. It receives' but a few short, insignificant affuents from the south, while the streams whioh pay tribute to it from the north are much larger, more numerous and much more widely branching. While lying wholly in the Iowan drift plain, Wolf creek is an excellent example of the eastward flowing streams which have developed one sided basins; the major stream having cut its channel close to the south side of the area which it drains. MoGee noliced that many of the eastward flowing streams of the "loess drift" portion of the state presented this peculiarity, and, as applied to such streams in Poweshiek and Iowa counties, he suggested the follawing explanation.* $\mathrm{He}$ considers the drainage systems of the "loess drift" area to be determined by a number of planes the north rim of each being sharply uptilted and from this ridge the plane inclines southward in a long gentle slope; the east flowing waterway in each case being located along the foot of the gently inclined, southward slopes of the plane; the steeper northward facing slope of the stream basin being the shorter and more sharply sloping front of the next southward extending, gentle incline.

Professor Calvin thinks, however, that these unsymmetrical basins might have been developed from one original gently: slop ing surface drained-by eastward-flowing streams, which basins might: in their early history have been symmetrical ${ }_{\text {... }} \mathrm{He}$, shows that the slopes which face the north would suffer much less than those on the opposite side of the channel from the alternations of freezing and thawing and the consequent effects of erosion in

"MeGee: Pleistooene History of Northeaztern Iowa, Eleventh Ann. Rop. U. g. Geol. Surv. p. 412-413. 
early winter and spring. These northward facing slopes would also be less affected by summer droughts which tend to oheck the growth of vegetation and to render the surface more pulverulent and so more easily attacked by dashing rain storms. Thus as the channels of the streams became deepened the north side of the valley would recede more rapidly than the south. The south facing slopes would slowly become more gradual than those which faced the north and the streams on this side would cut back into the highlands more readily and at a more rapid rate, robbing the secondary streams developed on the south side of the adjacent northern drainage area. In this manner as the drainage basin became more mature it gradually became unsymmetrical and was converted into an sloping plane with the master stream along the southern margin at the foot of a shorter and steeper slope which faced the north.*

Whatever the explanation may be, it is certain that here in Tama county the present streams are following more or less per-

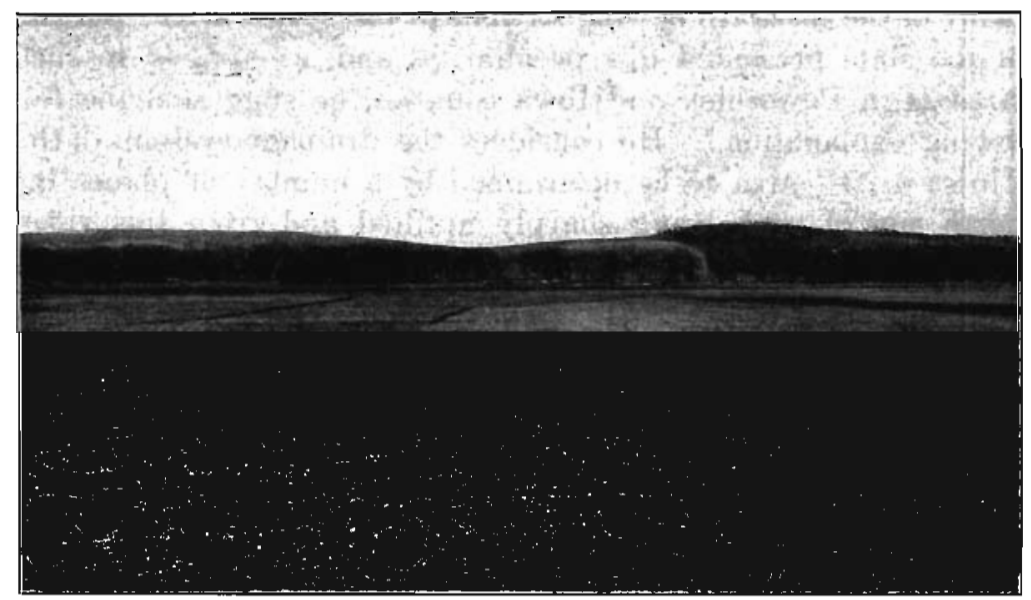

Fyg. 22. View looking west across the valley of Deer oreek, showing the bluffs which form the western border of the valley and which mark the weitern margin of the Toledo lobe of Iowan drift, Toledo townghip.

fectly the old channels of a drainage system which was impressed upon the area before the invasion of the Kansan ice sheet,

calvin: Iowa Geol. Surv., Vol. VII, p. su 
and, in most cases, valleys which were formed before the beginning of the Glacial epoch.

Deer Creek.-Deer creek rises among the low, rounded swells of the Iowan drift plain in the southern portion of the Spring Creek township. It follows a general southeasterly direction across Carlton township, the southwest corner of Howard and through. Toledo reaching the river in the south part of section 34 of the township of Tama. It flows in a broad valley one-half to three-fourths of a mile in width, the early history of which dates backward into preglacial times. On the east this valley is bordered: by the gentle slopes of the Iowan drift plain while on: the west the bluffs of Kansan drift rise bold and steep to a height of forty to fifty feet above the bed of the stream. 'Through numerous gaps in these bluffs the waters of small streams find

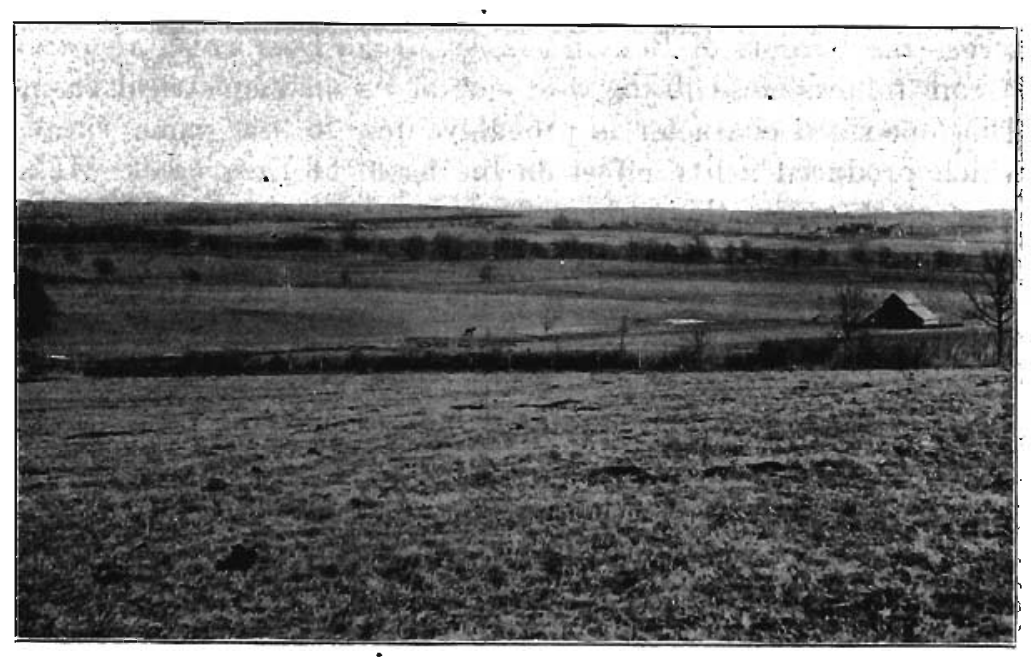

Fig. 23. View from the bluff on the west side of the valley of Deer creek, looking east across the valley and over a portion of the Toledo lobe. Bhowing the topography of the western portion of that are in Toledo township.

their way down to the creek from the uplands. From the east - the side of gentle slopes - a number of aftuents eight or ten miles in length pay tribute to this stream, among them Pin, Crystal, Pleasant, Jordan and Minnow oreeks, while from the west, a very much older surface, there are numerous short 
streams but not one of sufficient size ta merit a name: The basin; of Deer creek is one-sided but its lack of symmetry is probabty: due in part to the fact that the: west facing slope -was leveled by the Iawan glacier, while the east facing bluffs received the deposits which were laid down around the margin of the. Iowan ice.

Salt Creek.-Salt oreek is the largest tributary to the Iowa river from the north within the county. Its branches rise in the Iowan dirift plain, near the divide, in Crystal, Perry and Clark townships. Its basin drains an area of about 180 square miles in the east central portion of the county. As in the case of the Deer oreek valley, Salt creek is bordered on the west by abrupt bluffs of Kansan drift, which, at the same time, mark the western margin of the Iowan drift area in that portion of the county. To the east the Iowan plain stretches away in gentle undulations across the borders of Benton county. Like Deer creek also this stream follows close to the west side of its unsymmetrical basin. This one-sided character is probably due to the same causes which produced a like effect on the basin of Deer creek. Like Deer creek again, this stream flows. in a channel carred in the Kansan drift which fills a preglacial valley" of much greater size! it reaches the river near the east side of section 36 , of Salt Creek township.

Otter Creek.-Otter creek is a small stream which rises in Howard township within the area of the Toledo lobe of Iowan drift. It passes downward across the northeast corner of Toledo township, through Otter Creek township and across the northeast corner of Richland, joining the river not far from the center of section 21 , of Salt Creek township. Its basin embraces an area of about eighty square miles, including the greater part of . Otter Creek township and a small corner of the townships of Howard, Toledo, Richland and Salt Creek.

Sugar Creek.-Sugar creek rises in the northeast corner of Marshall county. It is not more than a: dozen or fifteen miles in length. It flows with the usual number of zigzag curves in a general southeast direction, reaching the river-near the west side of section 9 of Indian Village township. The chief character in which this stream differs from all others in the county is its 
Jouthfulness: : Its valley is quite wide, but not to be comouned in width with that of Bennett or Raven creeks - small streams which are no larger than Sugar creek. Then, too, it is still cutting at its banks and its bed. Ledges of limestone are exposed in the bluffs for some miles along the lower course of Sugar creek, a phenomenon to be seen along no other creek in the county.

Richland Creek.-Richland creek is the largest tributary to the Iowa river from the south within the county. Some of its branches rise near the western side of Richland township and -others have their source in the northwest corner of the connty of Poweshiek. The creek flows nearly due east for a distance of twenty miles-not considering the curves and bends in the channel-finding the river near the west side of section 13 of Richland township. Its valley is one-half to three-fourths of a mile in width and is covered with a deep, dark colored mantle of alluvium. The channel is bordered by hills of drift forty or fifty feet in height. Its basin is very narrow as compared with its length. The near presence of the Iowa river on the north has probably prevented the development of such a long slope on that side of the basin as is usually found in the basins of eastward flowing streams in this portion of the state.

Bennett and Raven Creeks.--Besides Richlard creek, the only streams of any considerable size which render tribute to the Iowa river from the south are Bennett and Raven creeks. Theso streams drain the northern portion of Highland township, the southeast corner of Indian Village and the southwest corner of the township of Tama. They are not more than eight to ten miles in length, yet they occupy wide valleys either one of which would be sufficiently large to accommodate the waters of the Iowa river.

In connection with all of the larger streams of the coursty the one thing which, again and again, strikes the observer with surprise is the great age of the valleys in which they flow. This extreme age is indicated by their great width and also by the absence of any rock ledges exposed in their bordering banks. It is a significant fact that each of these creeks rises within the Iowan drift plain, and it is very: probable that during the melt- 
ing of the Iowan ice these channels carried a much larger volume of water than they do at present.

History of the Drainage.-The channels of the present drainage system were probably outlined, for the most part, before the advent of the Pleistocene period. iWells which have been put down over the flood plain of the Iowa river penetrate to a depth of 170 to 230 feet before they reach the indurated rocks.

Along the lower course of Deer creek such borings indicate the presence of a channel 157 feet deeper than the bed of the present stream while in the southern portion of Spring Creek township there are exposed along one side of its valley bordering bluffs of oölitic limestone to a height of ten or twelve feet.

Near the southeast corner of Otter Creek township a well put down on the flood plain of Otter creek was bored to a depth of 200 feet before reaching indurated rocks. Wells put down along the valley of Salt creek penetrate to similar depths before encountering the layers of limestone.

Mr. Mosnat* has shown that the depth and distribution of the flowing wells of the Belle Plain area and the succession of deposits which they penetrate would indicate the presence of a deep valley excavated in the Lower Carboniferous limestone having a width of four to six miles and a maximum depth of 340 feet at Vining and 228 feet at Chelsea. Well borings show the presence of this ald channel from a few miles north of Vining down to the southeast corner of the county. It passes beneath Belle Plaine and on southeast into Iowa county as far as the town of Ladora. $\nmid$ This area embraces the more eastward extension of Kansan drift north of the Iowa river; and thus the portion of the county where now the hills stand highest, in preglacial times was the lowest and was occupied by the valley of a large river. The bottom of this valley contains drift of pre-JKansan age whiclı is overlain by a deposit of Aftonian gravels, which bed, in turn, is deeply covered with Kansan drift. These Aftonian gravels constitute the water bearing layer in this portion of the county. At Vining wells are sunk to a depth of 250 feet below the tops of the hills before reaching the bed of gravels, while in the

-Mosnat: Iowa Geol. Surr., Vol. IX, pp. 528-562.

+Ibid, p. 524. 
northern part of Otter Creek township a well has been sunk to a depth of 370 feet before the indurated rocks were encountered. It seems probable that in preglacial times this old valley carried the major stream of the region; and that to this river the streams which then occupied the channels of the Iowa river, Richland, Deer and Otter creeks rendered tribute.

\section{STRATIGRAPHY.}

\section{General Relations of Strata.}

The indurated rocks which are exposed in Tama counly belong to but one system of the Paleozoic group. They outcrop only along the middle portion of the western side of the area. To the north,east and south they are buried beneath a covering of drift which in some places is more than 360 feet in depth. It is probable that the rocks which immediately underlie the drift in the northeastern portion of the county are of Devonian age. There are no exposures, however, by which this presumption may be verified, but the first rocks which are encountered to the north and east belong to that system.

The superficial materials contain a record of the desolating action of three differont invasions of ice. Each glacial period was followed' by a milder interval of long durration during which the surface was clothed with vegetation and peopled with life very much as it is today.

The following table shows the geological formations which are known to be present in Tama county. 


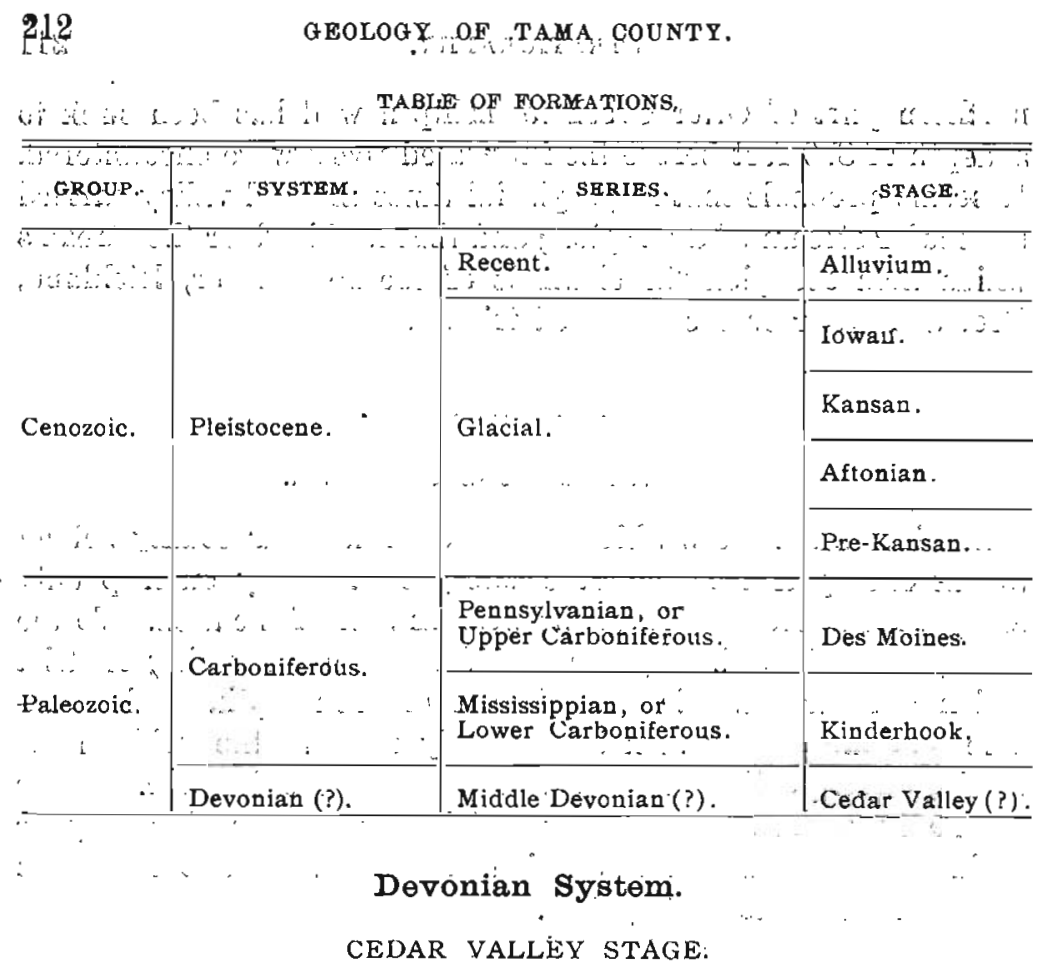

All of the indurated rocks which are known to be exposed at the surface in Tama county belong to the Carboniferous system, but all of the exposures which were found over the area occur in the western tier of townships. The successive strata of eastern Iowa outcrop at the surface in a general northwest-sontheast direction, and lines which in a general vay mark out the known area of the outcrops of the rocks of the Devonian system in the state would include the northeast corner of Tama county. The rock exposures which were found nearest to this portion of the county occur a few miles to the eastward along the tributaries of the Cedar river. At these points the uppermost members of indurated rocks belong to the Cedar Valley stage of the middle Deronian series. From the above consideration there seems little doubt but that the rocks of the same age immediately underlie the superficial materials as far westward as the borders of 'Tama county. 
"Oof the rock of the Carboniferous system there are found within the "area deposits of both the Pennsylvanian and the Mississippian series. Of the latter series there is represented only the lowest or earliest stage - the Kinderhook. Of the Pennsylvanian series there are found only sandstones which belong to the Des Moines stage.

\section{Lower Carboniferous or Mississippian Series.}

\section{KINDERHOOK STAGE.}

The name Kinderhook was applied to this assemblage of strata by Meek and Worthen* from the fact that the rocks of this age are well developed and typically exposed near the town of Kinderhook in southern Illinois. In discussing the Kinderhook beds as they are exposed in Tama county Professor Whitney speaks of their close resemblance to the Burlington member of the Carboniferous limestone as that member is developed at the city of Burlington. $\dagger$ Professor Hall referred the beds now included in the Kinderhook stage to the Chemung group of the Dovonian.t Dr. C. A. White designated the rocks of this stage as the Kinderhook beds, $\S$ and gives a section showing the character of the layers as they are exposed at Burlington through a vertical height of 109 feet.

The rocks of the Kinderhook stage in Iowa extend from Cerro Gordo county in the northwest to the bluffs of the Mississippi river in the county of Des Moines. As these rocks are exposed in Tama county they present three different facies. The lowest phase is a yellow, fine-grained sandstone which bears but few fossils and which is seen in but a few of the outcrops in the area. Overlying this sandstone is a stratum of light colored, oölitic limestone which occurs in thick massive layers. This phase is very fossiliferous throughout and is quite uniformly developed and constantly present wherever in the county the rocks of this horizon are exposed. The upper phase is a brown magnesian limestone which in some layers changes to a yellowish brown, fine-grained sandstone. The layers of this upper phase

\footnotetext{
-Meek and Worthen: Am. Jour. Bci, , Vol. XXXI, p. 223.

tEall: Geology of Lowa, Vol. I, pt. 1, p. 288.

IHall: Geology of Jowa, Vol, I, pt. 1, p 00.

WWhite: Geology of Iowa, Vol, I, p. 191.
} 
carry quite a number of fossils, usually in the form of casts or moulds. Near the upper part the magnesian oharacter gives way to thinly bedded limestone which in the uppermost layers exposed, carries a large quantity of the comminuted fragments of the stems of crinoids.

'The general obaracter of the rocks of the Kinderhook stage as those rocks are developed in this region, together with their order of superposition may be seen from a study of a few typical sections.

Typical Exposures.-Near the east side of section 17 of Indian Village township, in an old quarry just on the south side of the town of Butlerville, there is exposed the following succession of rook layers.

FEET. XX

14. Yellowish brown loess . . . . . . . . . . . 2

13. Brown clay containing numerous crystalline pebbles ........................ 6

12. Bed of grayish brown, impure limestone which breaks up into narrow layers and irregular pieces when exposed to the action of the weather. Fossils rare............... 3

11. Band composed largely of noduies of chert...

10. Impure limestone, brown in color, with few fossils, species of Chonetes, Rhynchonella and Spirifer were found............... I

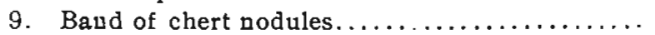

8. Thick, heavy layer of brown magnesian limestone containing casts of Chonetes and Rhynchonella ...................... 26

7. Layer composed mostly of nodules of chert.... 4

6. Layer of brown magnesian limestone with casts of Zaphrentis, Chonetes and Rhynchonella...

5. Brown limestone with numerous chert nodules intermingled, containing casts of a species of Productus .............................

4. Massive layer of brown magnesian limestone in which there is a considerable quantity of sand 4

3. Heavy layer of oölit 2 which weathers into small irregular blocks and bits, containing in abundance Orthothetes crenistria a species of Rhynchonella, Spirifer extenuatus, Spirifer biplicatus and Straparollus latus..........5

2. Massive beds of oölite in two layers similar to number 3 above and carrying similar fossils the lower portion somewhat talus covered.... 8

1. Yellowish sandstone with some clay containing few fossils, not well exposed, to level of road. 8 
A few rods to the west of this exposure, near the house of Mr. Blodgett, there is an outcrop of a few feet of thinly bedded, impure limestone which would occur above the uppermost member

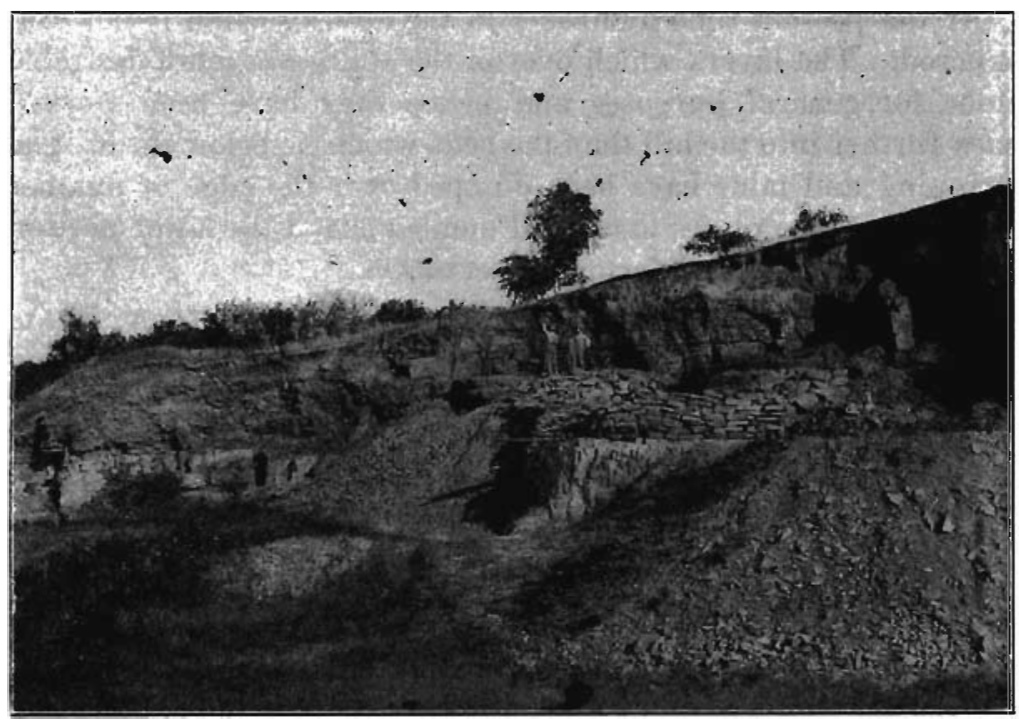

Fig. 24. View of the Butlerville quarry in section 17 of Indian Village townghip. The heavy ledge exposed at the base is oolite. The layers worked constitute the arenaceo-magnesian bed which immediately overlies the oolite.

of this section, the upper layers of which are crinoidal in character.

The beds above number 3 contain a few fossils but not nearly so many as appear in the layers of oölite. The quarryman, Mr. Dawson, stated that he had found numerous fish remains and crinoids in the seams which part the layers of magnesian limestone. Numbers $4,6,8$ and 10 of the layers of magnesian limestone are the rocks mostly used for purposes of masonry. The oolite yields rapidly to the weathering action of the atmosphere, crumbling into small irregular pieces. This oollite was formorly burned in large quantities for lime.

All of the beds at this quarry are cut by numerous wide joints into irregular blocks. Some of these joints are filled with a dark 
colöred, highly carbonaceous shale, which is very probably of Upper Carboniferous age. - However, the Coal Measure, deposits. have all been removed from the upper surface of the rocks in. this quarry.

i At the present time number 1 in the âbove section is not well exposed. The layers which overlie the oolite are more desirable stone for general purposes and hence they have been worked back further into the hill than the beds which lie below them. The stripping and talus have been dumped over the edge of number 3 so as in some places to conceal number 1 and the lower portion of number 2 from satisfactory observation.

In his report on the Geology of Iowa, Professor C. A. Whitegives the following section of this same quarry as it was exposed. in 186?.*

3. Soft, irregularly bedded, magnesian limestone passing up into purer and more regularly bedded limestone ...........................40

2. Light gray oölitic limestone in heavy layers...... 15

1. Yellowish, shaly, fne-grained sandstone , .... 20

In the above section it will be readily seen that number 1 corresponds with number 1 of the section of the Butlerville quarry as it appears today. Number 2 of White's section is the equivalent of numbers 2 and 3 of the present quarry section while number 3 of White's section includes numbers \pm to 12 as they areat present exposed at the Butlerville quarry. At the time Dr. White visited the region the beds below the oolite were better exposed and to a much greater depth; the limestone layers at the top were also to be seen in greater thickness than they are today.

About"one and one-fourth miles west of Butlerville, near thescuthwest corner of section 8 , a quarry is opened on land owned by C. J. Stevens of Montour. At this place the outcrop presents the following section:

* White: Geol. of Iowm, Vol. I, p. 196. 
15. Gray crinoidal limestone which weathers into thin pieces $\ldots \ldots \ldots \ldots \ldots \ldots \ldots \ldots \ldots \ldots$.

14. Crinoidal limestone, gray in color, with numerous fossil fragments ..................

13. Fissile limestone in thin layers, few fossils..... 4

12. Brown magnesian limestone with layer of chert nodules two inches in thickness at the top....

11. B $\mathrm{d}$ of rather soft, friable sandstone, much water seamed and containing numerous chert nodules, fossils few....................7

10. Arenaceo magnesian limestone, fine-grained and quite hard, brown in color. layers 8 to 12 inches in thickness containing casts of a species of Chonetes, Productus, Rhynchonella and Spirifer...............................

9. Bed of incoherent, brown, fine-grained sand... I

8. Band made up of chert nodules.............

7. Impure arenaceo-magnesian limestone, few fossils........................... I 1

6. Bed composed largely of nodules of chert carrying a layer of sand, 3 inches in thickness..... I

5. Magnesian limestone containing some finegrained yellow sand $\ldots \ldots \ldots \ldots \ldots \ldots \ldots \ldots 1$

4. Bed similar to number 5 above............ I 6

3. Layer of massive oülite weathering into small bits and bearing numerous fo:sils among which appear Ortholheles crenisira, Spirifer biplicatus, Spirifer cf extenuatus and Straparollus latus .......................... 7

2. Layer similar to number 3 above in lithological characters and fossil contents ........... 4

1. Layer of light gray oölite similar to numbers 2 and 3 above $\ldots \ldots \ldots \ldots \ldots \ldots \ldots \ldots \ldots$

In the above section it will be seen that numbers 1,2 and 3 are the equivalents of numbers 2 and 3 of the Butlerville exposure. The sandstone at the latter place which underlies the oölite does not appear in the above section. The impure limestone bed which includes layers 4 to 12 of the above section corresponds with layers 4 to 11 inclusive of the section at Butlerville. The upper limestone, which includes layers 13 to 15 above, represents number 12 at the Butlerville quarry and probably also embraces the limestone layers which appear in the hill near Mr. Blodgett's house. 


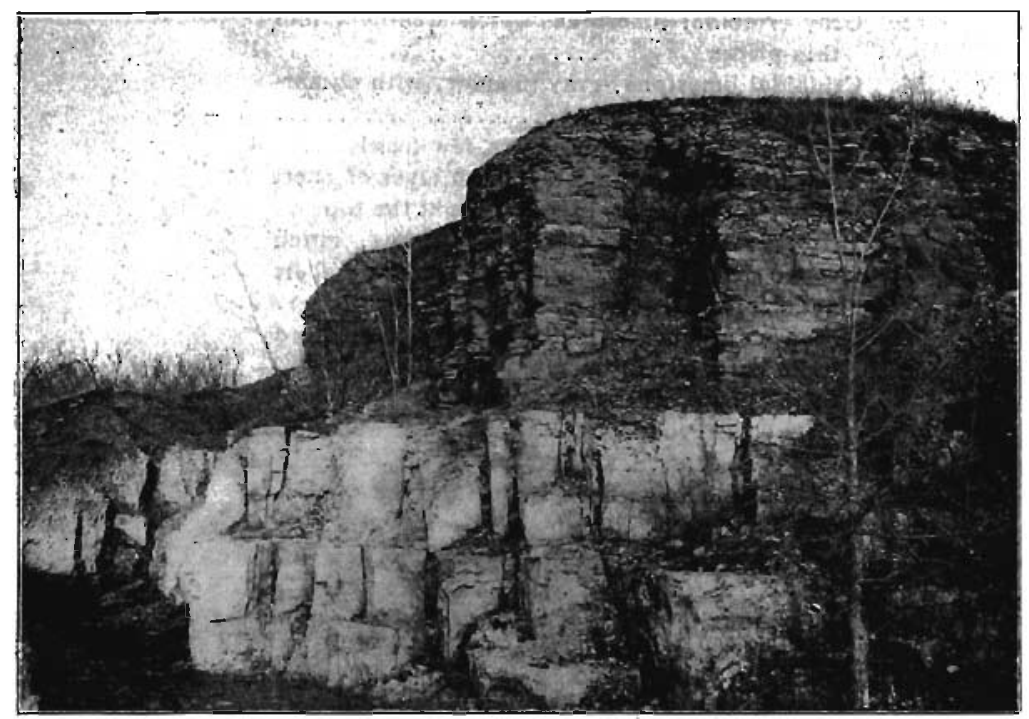

Fig. 25. View in the Stevens' quarry in section 8 of Indian Village township. The light colored massive bed at the base is oolite. The thin layers at the very top are limestone. The sand and impure limestone layers between contain numerous nodules of chert.

In the southwest quarter of section 21 of Indian Village township there is exposed in a ravine a short distance west of the town of Montour the following section:

3. Reddish brown clay with numerous pebbles.......4 4

2. Layer of light gray oölite containing numerous fossils, among them the following are abundant Orthothetes crenistria, Spirifer cf. extenuatus, $S$. biplicatus and Straparollus latus......6 6

1. Layer of oolite similar in every respect to number 2 above.......................... $3 \frac{t / 2}{2}$

This is an abandoned quarry which was formerly worked by the Oxford Lime Company. The oölite makes as good a quality of lime as can be obtained from pure calcium carbonate. Large quantities of it were used for lime making before the railroads brought the better grade of lime, made from dolomite, within easy reach of the builder.

It is evident that numbers 2 and 1 above correspond with number 3 and the upper part of number 2 respectively of the Butler- 
LOWER CARBONIFEROUS OR MISSISSIPPIAN SERIES, $\quad 2 ! 9$

ville quarry, and with numbers 3 and 2 of the Stevens quarry section. At Montour all of the magnesian and sandstone layers which overlie the oölite at the Butlerville and Stevens quarries liave been removed by èrosion.

In the southern part of Spring Creek township there is exposed along the east bank of a branch of Deer creek a ledge of oölite to a height of ten feet. This outcrap is the most northern rock exposure known to occur within the county, while none were found further south than the one at Montour. The rocks along Deer creek are essentially similar in lithological characters and fossil contents to those exposed at Montour.

Near the southeast corner of section 7 of Indian Village township there is a narrow bluff of rocks extending northward into

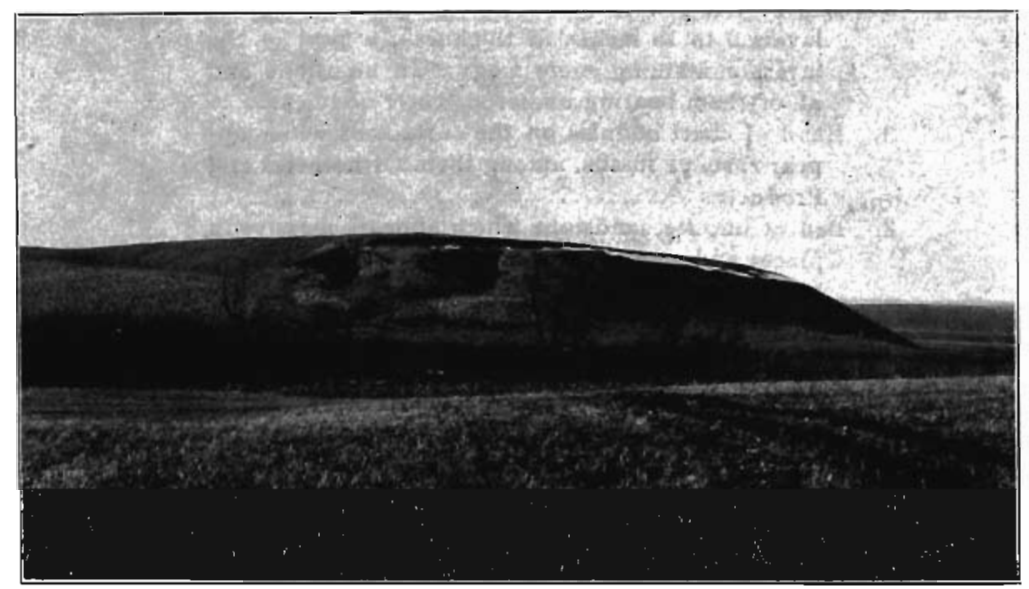

Fig. 26. The Devil's Anvil. A tongue shaped lobe of Kinderhook limestone extending dn to the Iow river valley in the gouthern part of section 7, Indian Vllage township. At the extreme righ appear the bluffs across the riper valley.

the flood plain of the Iowa river. This peculiar outlier has a vertical height of about fifty feet above the valley and is known locally as the "Devil's Anvil." There is exposed in the east side of this hill the following succession of layers: 
9. Reddish brown clay containing numerous small pebbles........................... 3

8. Bed of crinoidal limestone which weathers into thin layers 1 to 4 inches in thickiness ........... 7

7. Layer of crinoidal limestone bearing a band of chert nodules near the middle ................. 2

6. Bed made up of irregular layers of brown colored magnesian limestone 1 to 4 inches in thickness and containing numerous nodules of chert 6 to 12 inches In long diameter and 3 to 6 inches in the short direction. Casts of fossils not rare; among them appear species of Rhynchonella, Zaphrentis, Chonetes and Productus ................... 10

5. Impure magnesian limestone, brown in color, containing but few fossils and showing numerous cavities which appear to have been formed by the dissolving action of percolating waters ........4

4. Bed of fine-grained, brown colored sandstone in layers 9 to 18 inches in thickness, a part of the layers containing sobe magnesian limestone and all of them bearing numerous chert nodules.... 8

3. Band of chert nodules on the surface of which appear casts of fossils, among them Orthothetes and Productus ....................... $1 / 3$

2. Bed of impure sandstone which appears massive in places and at other places weathering into irregular layers 2 to 4 inches in thickness.......... 4

1. Bed of light gray oölite containing numerous fossil fragments amang which are Orthothetes crenistia Spiriter biplicalus and Slraparollus latus.......6 6

In this exposure only the upper layer of the oölite is to be seen and this is the equivalent of the upper portion of the oölite stratum in all of the sections previously given. The layers of arenaceo-magnesian limestone, represented by numbers 2 to 6 inclusive above are quite variable, the sandy character giving place to magnesian limestone, and the corresponding layers varying in thickness in exposures that are but a short distance apart. The aggregate of:these layers, however, is easily correlated with numbers 4 to 11 inclusive of the Butlerville quarry and with numbers 4 to 12 inclusive of the Stevens quarry section. The thickness of the limestone layers which overlie these arenaceomagnesian beds and which constitute the uppermost numbers of the rocks of the Kinderhook stage in the county is also variable at outcrops not widely separated, a larger amount having been 
removed by erosion at some points than at others. However, the corresponding beds as a whole can be readily recognized at all of the exposures' where these uppermost beds are present.

About three-fourths of a mile north of Butlerville in the south bank of the river there is an abandoned quarry which was formerly worked by Messrs. Stevens and Gray. At this place there is exposed about six feet of oolite at the base, which is succeeded by twenty-three feet of irregular layers of brown arenaceo-magnesian limestone interlaid with bands and numerous chert nodules. The indurated rocks are overlain by about six inches of oxidized bowlder clay and that in turn is covered with about one foot of loess soil. Outerops such as the last might be multiplied along the bluffs of Sugar oreek. In the last few: miles of its course the ledges of rock are exposed at almost every bend of the stream but there are no layers present which do not appear in the Butlerville, Stevens or Anvil exposures, nor were any species of fossils found there which were not seen at the points above mentioned.

The Butlerville section and the succession of heds which appear at the Stevens quarry and the Anvil may be taken as representative of the development of the Kinderhook rocks in Tama county. As will be seen the bed of whiteoollite is a conspicuous fear ture in each of these expasures.

In all cases the oolite of Tama county is mixed with a shell limestone, but the predominance of the oölite phase makes that the most conspicuous feature of these layers. Oölite is comprosed of small, more or less spherical, grains of calcareous matter cemented into a hard mass by the deposition of calcium carbonate. When a fragment of this rock is ground and polished, each little grain is seen to be composed of a number of thin concentric plates surrounding a common nucleus. Oölite was probably formed along an old sea margin which was submerged only during the periods of high tide; in places where, for some reason, the land stood almost at base level so that the streams which drained the surface carried to the sea little or no mechanical sediments; in a region where the climate was suitable for the rapid and abundant growth of brachiopods and other animals, which secrete skeletons of lime; in localities, too, where conditions 


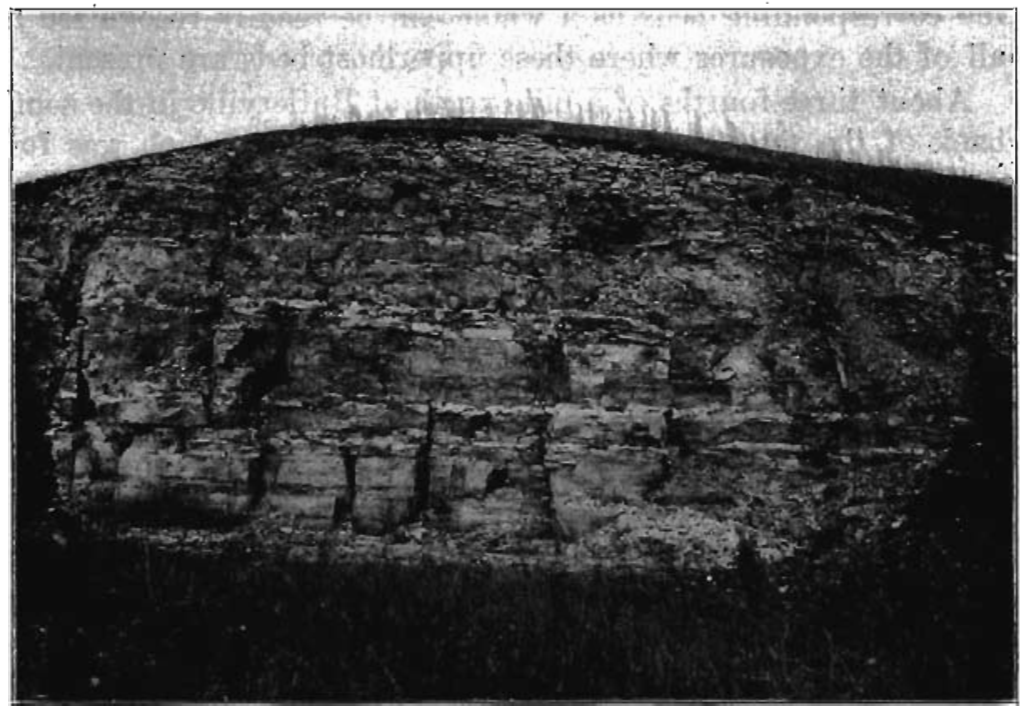

Fig. 27. Exposure in an old quarry near the soutbenst corner of section 8, Indlan Village township. The floor of the quarry is of colite, a little of which is shown at the base of the quarry. The middle portion shows bands of chert intercalated between the irregular layers of impure limestone. Thin layers of crinoidal limestone appear at the top.

were favorable for some concentration of calcium carbonate in the sea water. As the waves swept far up over such low beaches they would grind into tiny bits the fragments of shells which they rolled back and forth along the bottom and so cover the shore with minute grains of calcareous sand. Every time the tide rose and again receded a film of sea water would be left surrounding these tiny spheres which upon evaporation would deposit a pellicle of lime around the grain. In this manner the little spherules slowly grew by addition constantly on the outer surface. and finally the adjacent grains and fragments of shells were all firmly cemented together by an interstitial deposit of this same substance from the waters of that ancient sea.

It is by some such process as this that oölite is forming at the present time along the shores of tropical seas, and geologists believe that nature has worked in the past by the same methods as are used at present to secure like results. 
LOWER CARBONIFEROUS OR MISSISSIPPIAN SERIES. 223

The fossils which were found in the layers of oölite represent no great variety of forms but the individuals of the most of the species were very abundant. The following: were collected from this bed:

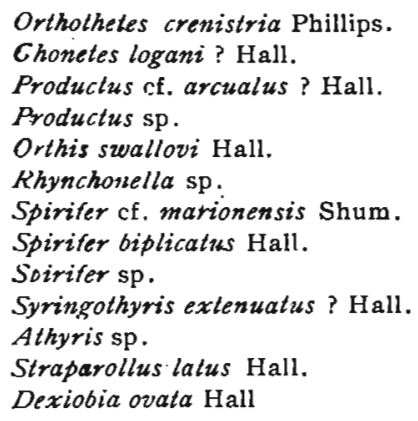

The layers of yellowish sandstone which underlie the oölite were seen at no point further west than the Butlerville quarry. At this place the beds were not very well exposed and no trace of fossils was found.

The arenaceo-magnesian beds which overlie the oollite were probably also deposited at no great distance from the shore along a zone that was subjected to variable conditions. They were formed during a period when the process of erosion was quickened and the streams brought down from the uplands greater quantities of sediment. The following animals peopled the waters during the time these rocks were being laid down.

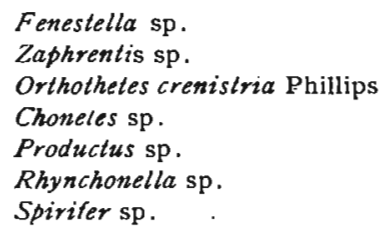

The limestone layers at the top of these sections record a gradual subsidence resulting in the diminution of erosion, allowing the building up of limestone layers from the shells or skeletal parts of the successive generations of sea animals, among which the crinoids were preeminent. The materials of these layers are so finely comminuted that but few of the fossil fragments. 
which they contain coxild be recognized. Among them were the following:

\section{Chonetes sp. \\ Rhynchonella sp. \\ Spirifer sp.}

Some time ago a collection of fossils from the above beds was sent to Professor Stuart Weller of the University of Chicago for identification, but up to the present date he has not had time to examine and report concerning them; hence the meagreness of the list of species found above.

In the discussion of the rocks of the Kinderhook stage in Marshall county, Dr. S. W. Beyer makes the following subdivisions."

4. Brown and gray subcrystalline limestone........30

3. Buff magnesian limestone, cherty below ........35

2. Gray-white oolite...................... 15

1. Argillaceous blue sandstone ................

Above number 4 he places provisionally about fifteen feet of argillo-calcareous beds which are exposed at Marshalltown, but which bear no fossils. In the Marshall county section number 1 is the equivalent of number 1 of the Butlerville section. Mr. Beyer speaks of observing casts of fossils in this bed but mentions none of the forms which they contain. Number 2 above corresponds with numbers 2 and 3 of the Butlerville quarry. Mr. Beyer speaks of this bed being fossiliferous throughout, among which forms he found:

\section{Entolium circulus Shum.}

Straparollus latus Hall.

Productus sp. and fish spines and plates.

In the third number above he found:

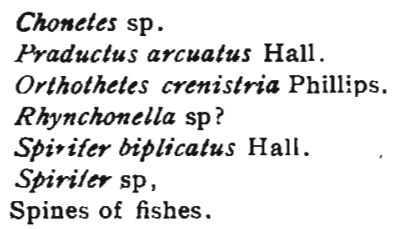

This number is identical with numbers 4 to 12 inclusive of the quarry section at Butlerville. It is probable that numlier 4 of

\footnotetext{
- Iowa Geol. Sarv, viol. VII, p. 22z, el sëq.
} 
Beyer's section is represented in Tama county by the limestone layers which overlie the arenaceo-magnesian beds at the Butlerville and Stevens quarries and in the Anvil exposure. It is not developed to such a thickness in Tama county as it is farther west. The shales which are found at Marshalltown have ro counterpart within the area under consideration.

In his report on the Geology of Iowa Dr. White gives the succession of the Kinderhook beds as they are exposed at the city of Burlington." The condensed reproduction of his Burlington section is given below.

\footnotetext{
7. Impure limestone, sometimes magnesian, passing gradually into the Lower Burlington, disintegrating more readily than the overlying Burlington limestone........................... 3-4

6. Light gray oolitic limestone, very uniform in Iithological characters..................... 2-4

5. Fine-grained yellowish sandstone, often crowded with casts of fossil shells, embracing many genera and species some of which are peculiar to this bed alone, The fossils of this bed are usually small Lamellibranchs and Brachiopods............. 7

4. Dark gray compact limestono, sometimes sllghtly arenaceous, breaking up into small fragments on exposure and is very fragmentary even when not exposed to the atmosphere . .................. 12
}

3. Ooblitic limestone, interesting as showing the tendency of the limestones of this formation to assume this structure $\ldots \ldots \ldots \ldots \ldots \ldots \ldots \ldots \ldots \ldots, \quad 1 / 4$

2. Layer of compact limestone everywhere crowded with shells, principally Chonetes........... $1 / 2$

1. Composed largely of fine-grained sandy shales, but varying from bluish clayey shales to fine-grained yellowish sandstone, greatest thickness exposed..82

No. 1 is recognized in well borings at a depth of 65 feet,below the above measurement, making the entire recognized thickness of this member 147 feet.

Mr. White considered number 1 of his Burlington section to be the equivalent of number 1 of his section of the Butlerville exposure; number 6 at Burlington to be the representative of number 2 at Butlerville, and number 7 at Burlington to be the counterpart of number 3 at Butlerville. ${ }^{-H e}$ seemed to think that

- White: Geol. of Iowu, pp. 192 and 198.

t Ibid: p. 198. 
numbers 3 to 5 inclusive of the Burlington section were not represented at Butlerville at all. Dr. White speaks of the upper portion of number 1 at Burlington being quite fossiliferous in some places and states that the characteristic fossils of the Kinderhook formation prevail throughout the whole series of beds found at Indiantown (Butlerville) but he does not mention any of the species that were found at either exposure. In the spring of 1899 Professor Stuart Weller made a study of the rocks of the Kinderhook stage as they are exposed at Burlington. Mr. Weller makes the following section of these rocks which differs from White's only in dividing number 1 and combining numbers 2 and 3 .* $^{*}$

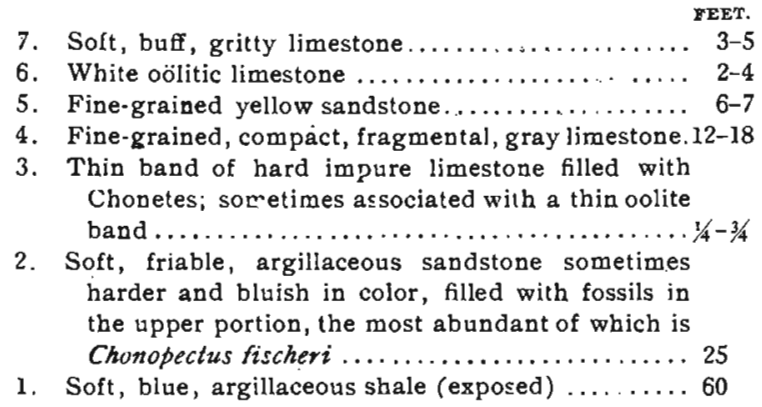

As will be seen numbers 4 to 7 inclusive of Weller's section are identical with the corresponding numbers in the section of Dr. White. In number 6 of the above section, which White considers the equivalent of the oollite layers in Tama county, Weller mentions the following list of fossils which have been observed $\dagger$

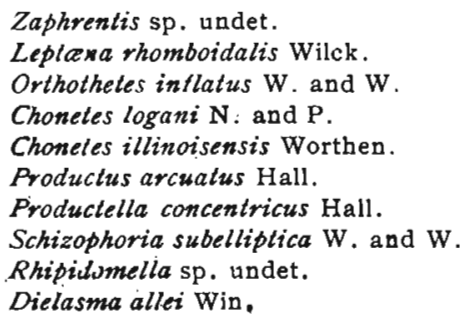

- Weller: Iowa Gcol. Surv., Vol. IX, p. eb.

+ Ibld : p. 78 . 


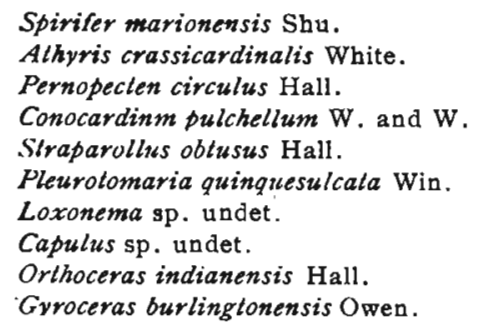

From bed number 7 of Weller's section, which White considered the representative of thearenaceo-magnesianlayers which overlie the oölite in Tama county, Mr. Weller names the following species:

Leplopora typa Win.

Orthothetes inequalis Hall. (?)

Orthotheles inflatus W. and W.

Productus punctatus Martin.

Camarophoria caput-testudinis White.

Rhvnchonella persinuala Win.

Spiriferina solidirostris White.

Nucleospira barnsi White.

Bellerophon panneus White.

Pleurotomaria mississippiensis W. and W.

Igoceras undata Win.

Capulus paralinus W. and W.

Capulus zomerium Win.

From a comparison of the fossils which appear in number 6 of the Burlington section with those which occur in the oölite beds of Tama and Marshall counties, which members Dr. White thought were equivalent, it will be seen' that there 'is à very marked difference between the fauna of the respective members. It is possible, however, that when Mr. Weller completes the study of the fossils of the Kinderhook stage in central Iowa that these differences may become less conspicuous, and the resemblances may grow more apparent. In like manner the assemblage of fossils which is found in the arenaceo-magnesian beds overlying the oölite in Tama and Marshall counties is quite different from that found in number 7 of the section at Burlington, with which member Dr. White considered the arenaceo-magnesian beds to correspond. 
If the rooks of the Kinderhook stage which are found in Tama and Marshall counties were deposited contemporaneously with any of those of the corresponding stage at Burlington, it is possible that Dr. White was correct in his corrolations as given above. Lithologically the oolite beds of this horizon in central Iowa resemble very closely number 6 of the Burlington section. A larger proportion of the fossils which are found in the oölite layers is similar to those found in number 6 than to those of any other member of the Burlington section. Also the beds immediately overlying the oölite in Tama and Marshall counties are as nearly similar in lithological characters and fossil contents to number 7 as to any other member of the section at Burlington. It will be evident, however, that if this is the true interpretation of the relation of the Kinderhook rooks which occur in the counties of Tama and Marshall to those exposed in the bluffs along the Mississippi river at Burlington, there must have been very peculiar conditions attending the deposition of these materials to result in the wide differences in the animals which peopled the waters along that ancient shore at the two points separated by such a short distance. What those conditions could have been is not at present understood.

The limestone beds of the Kinderhook stage which overlie the arenaceo-magnesian layers in central Iowa seem to have no probable equivalent further south. The sandstone member which underlies the oölite in Tama and Marshall counties is not suffciently well exposed over this area to permit even an approximate determination of its equivalent in the exposure of the rocks of this state at the city of Burlington.

\section{Upper Carboniferous or Penneylvanian Series.} DES MOINES STAGE.

The deposits of the Lower Carboniferous series were closed by a crustal movement that raised this portion of the state above the sea. For an exceedingly long period, measured by three geological ages, the area which embraces Tama county was a land surface, exposed to all the denuding effects of weathering and erosion to which such areas are subjected at the present timo. Deep gorges and wide valleys were carved in the level strata of 
the Kinderhook stage and doubtless a great depth of rock materials which were once laidi down above the highest layers that at present are found in the area was swept entirely from'the surface and carried down to the sea, contributing to the sum of the sediments which make up the rocks of the Augusia and the Saint Louis stages farther to the south and west.

Finally the oscillations of the crust resulted in the submergence once more of the greater portion of Iowa. The area under discussion was involved in this catastrophe, and deposits of sediments once more accumulated over the region, filling all of the old valleys and burying deeply the gashed and furrowed surface beneath a covering of sand and shale and seams of coal which constitute the deposits of the Des Moines stage of the Pennsylvanian series.

This portion of the state did not remain beneatl the waters so long as areas lying further to the south and west. With an upward movement of the crust the region was again added to the domain of the land. This new land was immediately attacked by the quiet agents of the atmosphere and the more rapid action of the rains and streams. During the rest of the Paleozoic era, the whole of the Mesozoic and the greater portion of the Cenozoic it was being: carved and worn and wasted; reduced to base level, only to begin a new cycle of erosion with each new elevation of the land. The whole of the deposits of the Des Moines stage was eroded from the surface except a few small patches accupying old channels in the Kinderhook rocks, which were not again appropriated by later streams. Protected in these depressions from. the general denudation that removed the great mass of the sediments of the Des Moines stage, these isolated remnants witness to the profound changes which this region has undergone.

Near the central part of section 9 of Indian Village township there is exprosed in a ravine on the north side of the wagon road a bed of sandstone about six feet in depth which was thought to be of Des Moines age. The sand here is quite incoherent when long exposed to the weather, except where the grains have been cemented together with an interstitial deposit of iron. It is yellowish brown in color and coarser grained in texture than any that had been found in the deposits of the Kinderhook stage in that region. 
No remains either of plants or animals were found in these layers. This bed was in a valley thirty feet lower than the tops of the ledges which form the bluffs of the Iowa river scarcely one-half mile away. The pockets and joints filled with carbonaceous shale which are found at the Butlerville quarry would also indicate that the entire surface of the county had been covered with these Upper Carboniferous deposits, the most of which had subsequently been removed by erosion before the beginning of the Pleistocene period.

\section{Pleistocene System.}

During the excedingly long interval that elapsed between the elevation which closed the deposits of the Upper Carboniferous series over this area and the initiation of the Pleistocene period not only had the surface suffered great denudation and deep erosion but the rock materials had slowly disintegrated in excess of what was removed by the streams and thus a soil was formed which, as it gradually grew deeper, protected the underlying rocks from the most rapid decay. Slowly as the soil accumulated plants appeared, and at length the surface became clothed with vegetation and peopled with abundant forms of animal life. It was after the long continuance of such a condition of things as this that the Pleistocene period was introduced. During the early part of this period ice sheets were pushed down from the north over this area, bringing with them great quantities of clay and bowlders and rock debris. These materials were spread out over the surface of the county to such a depth that the streams have succeeded in cutting their channels through the covering of drift in but few places so as to reveal the indurated rocks which underlie it. The Glacial series is represented in Tama county by three different sheets of drift, deposits of loess and beds of alluvium.

\section{PRE-KANSAN DRIFT.}

Near the southwest corner of section 19 of Toledo township a cut has been made in a hill in order to make wider the road bed of the Chicago and Northwestern railroad. At this place the following section has been exposed.*

\footnotetext{
- Gavage: Drift Expagure In Tama county, Proc. Iowa Acad. of Sciences, Vol. VIU, p. 275.
} 
5. Fine-grained, yellow colored clay without gravel or bowlders ......................... $41 / 2$

4. Bed of sand in alternating bands of finer and coarser grained material. . . . . . . . . . . . . . . . 8

3. Bed of bluish colored clay containing numerous pebbles and bowlders many of which are dec iyed. . 24

2. Band of brown colored, somewhat sandy soil containing impressions of vegetable remains and pieces

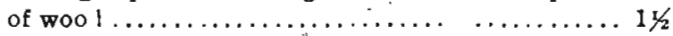

1. Bed of blue clay with numerous pebbles and bowlders down to the base of the exposure, pre-Kansan. 16

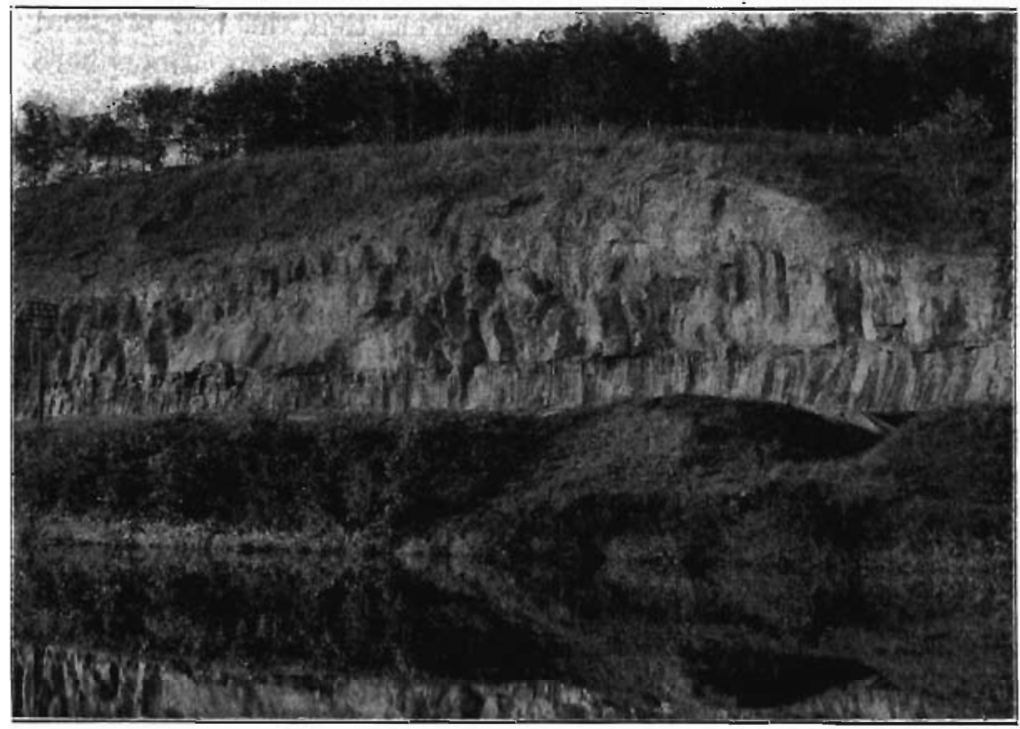

Fig. 28. Exposure in a cut along the Chicago \& Northwestern Railuoad near the southwest ern corner of section 19. Toledo township. The drift at the base is pre-Kansan, that at the top is of Kansan age, the horizontal band a little below the radddle of the section represents an old Aftonian soll horizon. (Photo by Mr. J. M. R. Hanson.)

In the above section number 5 is the common fine-grained, yellow loess that forms the surface soil aver the most of the neighboring uplands. Number 4 is a bed of loose sand in which the layers of finer-grained material alternating with those of coarser texture indicate a deposit along the channel of a stream in which the strength of the current was variable. The layer of sand was probably deposited along the bed of a stream that 
carried off the waters which resulted from the melting of the Kansan ice. Number 3 is a thick bed of bowlder clay, containing numerous pebbles and bowlders of various sizes, many of which show marks of glaciation. Quite a large proportion of these pebbles and small bowlders are dark colored greenstones. Many of the light colored bowlders have so far decayed that they soon crumble to pieces when exposed to the air. This bed of clay represents the Kansan drift. It is of a yellowish color at the top, gradually changing to a bluish color lower down. It is calcareous even at the top which is unusual for the surface of the Kansan drift sheet. It is probable, however, that the bed of sand which overiies this drift has so protected it from the atmosphere as to prevent the leaching of the lime from the clay for some few. feet below the surface, as has generally taken place at the upper part of this drift. The bed is cut by numerous joints and cracks into prismatic and irregularly shaped blocks and fragments. Number 2 is a narrow band of dark brown materials composed of more or less perfectly decayed vegetable mattel mixed with a soil which contains a considerable amount of sand. This band contains no trace of calcareous matter. Fragments of wood, bits of roots and dark colored patches of carbonaceous material occur near the upper part of the bed. It forms a conspicuous layer eighteen to twenty-four inches in thickness, which is exposed at this horizon for a distance of several rods. Number 1 is a bed of bowlder clay which resembles number 3 above in color and contents. It does not present such numerous joints as appear in number 3. At the top of the nember the oxidation of the iron in the clay has given to the till a slightly yellowish appearance but this change is not nearly so marked asi is often seen at the surface of the Kansan drift. The calcareous matter has been almost entirely removed to a depth of one to thr'ee feet. A few feet below the soil band prompt andivigorous action when treated with hydrochloric acid reveals the presence of abundance of lime down to the base of the exposure. This lower bed of till is considered of pre-Kansan age. The narrow band containing plant remains and soil constituents represents the old surface of the Aftonian interglacial period, during which interval the leaching at the top of the lower bed of till was slowly accomplished. 
In well borings at different points over the county the same bed of bowlder clay is encountered underlying the Kansan drift, but this is the only place within the area where it is known to be exposed at the surface.

A well put down in the spring of 1902 by Mr. William La Due of 'Toledo, for the Toledo and Tama Electric Car Company, about the middle of the south side of section 20, Toledo township, passed through the following succession of beds as furnished by. the well driller:

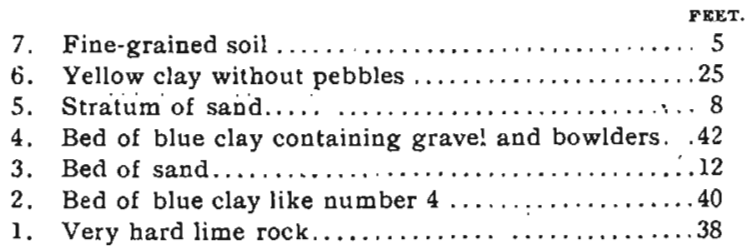

It is probable that numbers 6 and 7 of the above section represent a deposit of loess, the upper part of which has been changed to a darker color by the carbonaceous matter that has been left from the decay of successive generations of vegetable forms which grew upon the surface. Number 5 is a sand bed that was probably laid down along the channel of a stream which carried water while the Kansan ice was melting, but which was abandoned when the ice withdrew from the area and the stream found a lower level for its bed. Number 4 is evidently a bedi of Kansan till with its natural color and contents. Number 3 rẹpresents a sitream deposit of sand that was laid down either during the time of melting of the pre-Kansan ice or in the interval of the Aftonian interglacial period. Number 2 is a bed of preKansan drift which presents the characteristic blue color of this lowest sheet of till as it appears at other points over the state. No fossils were preserved from number 1 of the above section so it is impossible to determine fully the age of the limestone encountered immediately below the drift at this point. From the proximity to the exposures of the rocks of Kinderhook age it would seem probable that these rocks might belong to the basal portion of that stage. However, the lower members of the Kinderhook rocks as they are exposed in Iowa are sandstones or $18 \mathrm{G}$ Rep 
shales rather than limestone and it may be that the strata encountered. in the well boring belong to the Devonian series.

A well drilled on land owned by T. B. Kepler passes through a succession of materials similar to the above but the beds of drift are not so thick. A well drilled on land ownedl by W. B. Mitchell in Otter Creek township penetrated the following succession of beds :

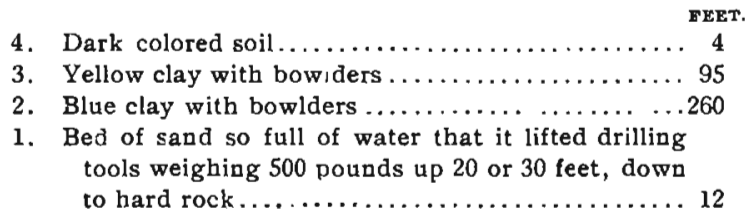

This farm lies within the limits of the Kansan drift plain. In the above record number 4 is a deposit of loess. Numbers 2 and 3 doubtless represent Kansan drift. This drift is usually a bluish gray color in deep beds and it is very remarkable that oxidation should have taken place to such an extent as to give the deposit a yellow color to the depth of ninety-five feet. In number 1 there occurred numerous pieces of wood two to three feet in length and one inch in diameter. The sand also contained numerous fragments of shells. The bed was doubtless occupied by the waters of a stream which drained a portion of this region during the Aftonian interglacial period. The source of the materials may have been the drift of pre-Kansan age or possibly the sand may have resulted from the decay of native sandstone rocks. As will be seen the indurated rocks at this place are buried beneath a deposit of superficial materials 370 'feet in depth. This is the greatest depth which these materials are known to have attained within the county.

Mr. Masnat* has shown that in putting down a well, which he designated as number 98 , at Belle Plaine, only about one and onehalf miles from the southeast corner of Tama county, the drill passed through layers which are essentially as follows:

4. Fine-grained loess..................... 15

FEET.

3. Bluish colored bowlder clay of Kansan age.......210

2. Gravel and sand of Aftonian age............ 5

1. Bed of blue till representing the pre-Kansan drift.. 18

- Mosnat: Iowa Geol. Surv., Vol. IX, p. 587. 
Number 2 is the water-bearing, reservoir which is the source of the water in the flowing wells of the Belle Plaine area. There are a number of such wells in the southeast corner of Tama county and there seems no reasonable doubt that the above section represents the general arrangement of the superficial materials orer all of the area in which strong flowing wells occur. If this interpretation be correct there is evidence of a sand and gravel bed of Aftonian age underlain by a bed of pre-Kansan till over quite an area in the southeastern portion of this county.

It seems probable that the pre-Kansan drift was a thin sheet which carried an abundance of gravel and that erosion removed a large part of its materials from the uplands before the incursion of the Kansan ice. At least, we have at some points indubitable evidence of an old drift underlying the Kansan and separated from it by a bedl of water laid materials or an old soil horizon, the line of contact between the two beds being exposed in the railroad out deseribed above, while the records of a large number of wells show just as clearly the Kansan drift immediately overlying the indurated rocks over the greater portion of the county.

\section{KANSAN DRIFT.}

The area over which the Kansan drift forms the surface till of the county has been outlined under the disoussion of topography. The materials of which this drift is composed are very old. The bowlders which it contains are usually much smaller than those carried by the Iowan ice. A larger proportion of them are miorocrystalline, dark-colored basic rocks known as greenstones. Many of them have been carried along beneath the ice during a portion of their long journey and present one or more surfaces that have been beautifully planed and striated. A large proportion of the light-colored granites are so thoroughly decayed that they crumble at once into small bits when the surrounding clay is removed.

As the Kansan ice sheet with its crushing weight of materials was pushed down over the old Aftonian surface it gathered up and carried along with it the most of the pre-Kansan drift that still remained on the uplands. It also bore onward the geest and 
residuum of the partial decay of the native limestone rocks which had been accomplished since the retreat of the first ice sheet, grinding down into the solid ledges and leaving below it a hard surface which was planed and striated by the rocks of the ground moraine as the mass of ice slowly moved along. Such a glaciated surface exposed for several square feet and overlain by Kansan. drift was seen in a quarry in the north bank of the river near the Tama and Marshall county line. These calcareous materials which were gathered up from the rock surfaces became so thoroughly mixed through the Kansan till that the entire deposit was permeated with carbonate of lime. The surface of this sheet has been so long subjected to the leaching action of the rains and to the effects produced by the growth and decay of countless generations of plants, that the lime has been entirely removed. to a depth of two to five feet. The iron also which the drift contained has been so long exposed to the oxidizing action of the atmosphere that to a depth of three or four feet the clay presents a dark reddish-brown color, instead of its typical bluish-gray, on account of the ferric axide which it contains. For several feet below this red colored zone the clay is usually a yellowish-brown, grading down into the unchanged drift sometimes at a depth of fifteen to twenty feet. Examples of such surfaces of red colored clay which is thoroughly leached of calcareous matter are exposed in the ravines along the roadside between sections 29 and 30 of Richland township and again along the south side of section 17 of Toledo township, and at numerous other points over the county. In fact, this is the usual condition of things wherever the Kansan drift is exposed for a few feet below the surface.

So exceedingly old is this sheet of till that its surface was practically carved as deeply and dissected as thoroughly as it is today before the advent of the Iowan ice. This is evidenced by the fact that the hills immediately adjacent to the border of the Iowan drift plain, which received deposits of loess and sand during the time the Iowan ice prevailed, present a leached and oxidized zone at the line of contact between the drift of the hill and the loess or sand which forms its crown. This oxidized zone is continued well down the flanks of the slopes. The loess and sand were laid down over a surface which had essentially the present 
erosional features before their deposition, those beds only increasing a little the difference in aititude between the valleys and the tops of the hills. Over the more deeply loess-covered regions of the county - and all of the Kansan area is loess covered-the ravines along the roadsides in multiplied instances reveal the old oxidized surface of the Kansan conforming with the present contour of the hills; the top of the loess mantle lying parallel with and duplicating almost every inequality in the surface of the underlying drift.

The following well records from various points in the county reveal the till of Kansan age immediately overlying the indurated rocks.

In section 1 of Toledo township a well on land owned by J. W. Schooloraft penetrated the layers indicated below:

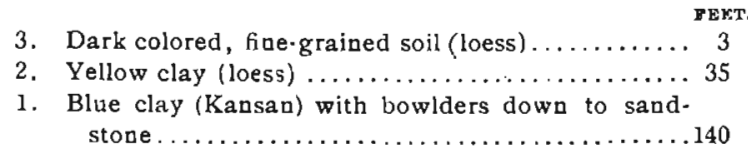

In section 7 of Otter Creek township a well on the farm of Mr. Elmer Dowd gave the following succession of beds :

FEET.

4. Yellow clay, fine grained (loess) ........... 40

3. Blue clay with bowlders (Kansan) ........... 175

2. Shale rock (Kinderhosk)............... 25

1. Hard limestone ..................... 78

In section 17 of Toledo tow nship a well drilled on the farm of J. A. Berger shows the following:
7. Soil, fine-grained (loess) $\ldots \ldots \ldots \ldots \ldots \ldots \ldots \ldots, 4$
6. Yellow clay with gravel and small stones (Kansaz. 40
5. Blue clay with bowlders (Kansan)...........176
4. Shale ........................... 5
3. Limestone ......................... 20
2. Shale ........................... 160
I. Hard, blue limestone................... 15

In the town of Chelsea, Salt Creek township, a well on land owned by J. W. Shaler gives the following record:

5. Dark colored soil (alluvium) ............. 4

4. River deposit of clay, sand and gravel (Recent) .. 33

3. Blue clay with bowlders (Kansan) . . . . . . ....... 148

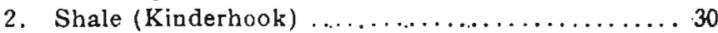

1. Limestone, hard (Devorian).............. 18 
A well in section 29 of Salt Creek township on the farm of J. P. Wilkson penetrated the following beds:

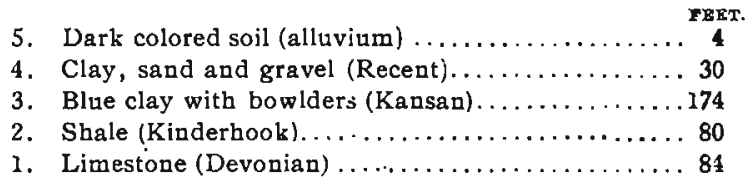

In section 36, Otter Creek township, a well section on land owned by N. Blazek is as follows:
5. Soil (alluvium) $\ldots \ldots \ldots \ldots, \ldots \ldots \ldots \ldots \ldots \ldots, 5$
4. Water-laid materials (Recen ) .. ............. 30
3. Blue clay (Kansan) ...................... 165
2. Shale (Kinderhook) ..................... 100
1. Hard limestone (Devonian) $\ldots \ldots \ldots \ldots \ldots \ldots \ldots, 20$

Mr. McGee gives the following record of a well drilled in section 13 of Clark township for the Chicago \& Northwestern Railway:

4. Yellow clay containing pebbles (Iowan) ........ 12

3. Sand (Inter-Kansan-Iowan) ................ 19

2. Blue clay with bowlders Kansan).............150

1. Sand (Aftonian) $\ldots \ldots \ldots \ldots \ldots \ldots \ldots \ldots \ldots \ldots \ldots, \ldots \ldots \ldots$

The first three of the above records were furnished by the well driller, Mr. W. H. La Due of Toledo. The three following were taken from Mr. R. Mosnat's report on the artesian wells of the Belle Plaine area* and the last one was taken from W. J MoGee's Pleistocene History of Northeastern Iowa. $\dagger$

Gravels.-There are no gravels of Buchanan age known to occur in Tama county, but on the hill slopes in a few places there are thin sheets of pebbles and small bowlders overlying the Kansan till which simulate deposits of the Buohanan gravels. Professor Calvin found at different points in Page county a layer of gravel conforming to the line of contact between the Kansan till and the overlying loess. + He has shown that the gravel in these sheets was originally distributed through that part of the Kansan drift whioh has subsequently been removed by erosion. The finer alay portion of the till was easily carried away by the waters

- Mosnat: Iowa Geol. Surv., Vol. IX, p. sbe.

+ MeGee: Eleventh Ann. Rep. U. S. Geol. Surv., p. 520 .

J Calvin: Iowa Geol. Snrv., Vol. XI, pp. 442 and 448. 
which drained the general surface while the pebbles from quite a thickness of the drift, being too heavy to be carried along by the surface water, became concentrated in a thin bed by the removal of the finer materials. It is by some similar process that the thin gravel bed which overlies the Kansan drift along the roadside between sections 13 and 14 of Highland township and again between sections 19 and 30 of Howard township was formed.

IOWAN DRIFT.

The Iowan drift sheet extends over three-fourths of the surface of Tama county. The areas which it covers have been already described. As a general rule the Iowan ice which mored over the portion south of the river and over the Toledo lobe was so thin and the amount of materials which it carried was so small that in many places the erosional features of the Kansan till were not greatly modified. To diseriminate between such Iowan areas and those of the less eroded Kansan surface is not always an easy task. Usually, however, the Iowan ice left large bowlders of gray granite at more or less frequent intervals on the surface over which it passed. Wherever these appear in the fields and along the courses of the streams there are topographic features accompanying them which together constitute quite distinotive criteria. So constant is the presence of occasional bowlders over the Iowan area, even where it left but slight traces in the topography, that its outlines could almost be mapped from the presence of these fresh granite bowlders in the foundations of corn cribs and ather buildings on the farms over the Iowan plain. Usually only the smaller ones have been removed from the cultivated fields.

Adjacent to the larger streams the Iowan surface is well dissected and thoroughly drained. The tributaries, however, are usually short and they always rise in broad, ill-drained marshy sloughs with undefined channels which are utterly unlike the sharply angular trenches and furrows that form the source of the streams of the unmodified Kansan drift plain. The hills of these hybrid regions are slightly lower and present more rounded outlines than those in the Kansan area. They lack the sharp, bold contours and abrupt slopes so characteristic of the older drift surface. 


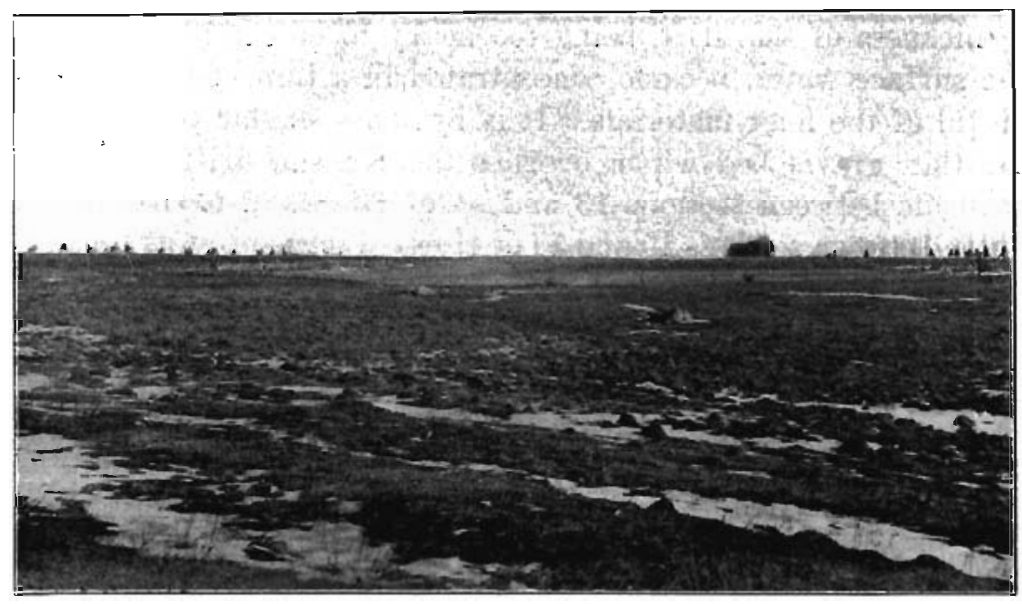

Fig. 29. Typical marsh in the Iowan drift plain. In such swamps the streams of the area take their rise.

Over large areas the finer materials of the Iowan drift have been entirely removed. The undisturbed, red-colored Kansan till, thoroughly oxidized and deeply leached, that appears at the tops of the hills and continues well down the slopes, testifies to tle very small amount of ice that has moved over them. Where the Iowan drift is exposed it is of the usual yellowish color, not.more oxidized at the top than at the base of the deposit, and unleached at the very surface of any of its calcareous constituents. Small beds of this drift are frequently seen at the foot of the hills over the hybrid areas, but care needs always to be exercised in its dis(rimination, for in color and calcareous contents this material resembles the portion of the Kansan drift lying between the thoroughly oxidized ferretto zone at the top and the unchanged blue clay of the deeper portions of the bed. Erosion has frequently exposed this yellow calcareous Kansan till near the base of the hills. This older drift, however, carries a larger number of pebbles and small bowlders, a large proportion of which are fine-grained and dark in color. The bowlders of granite are frequently much softened and decayed. At several places over the hybrid areas the yellow Iowan till is seen overlapping the ferretto zone of the Kansan, as along the north side of section 35 of Howard township, be. 
tween sections 23 and 26 of Crystal and between sections 13 and 14 of the township of Highland. Over most of the northern portion of the county the Iowan till presents a level unsculptured surface which is typical of this recent drift plain. Its youthfulness is depicted in every feature of this deposit. The agents of erosion have scarcely yet begun their work. The constituents of the till are unchanged at the very top. The granite bowlders are almost as fresh and sound as when they left their native ledges. Every criterion of age attests the recent deposition of the Iowan materials. In comparing the age of the Iowan drift with that of the Kansan, Professor Calvin says," "If it slould be claimed that the Kansan is a hundred times as old as the lowan, I know of no facts at present that would disprove the claim. If some one should estimate the age of the Kansan as

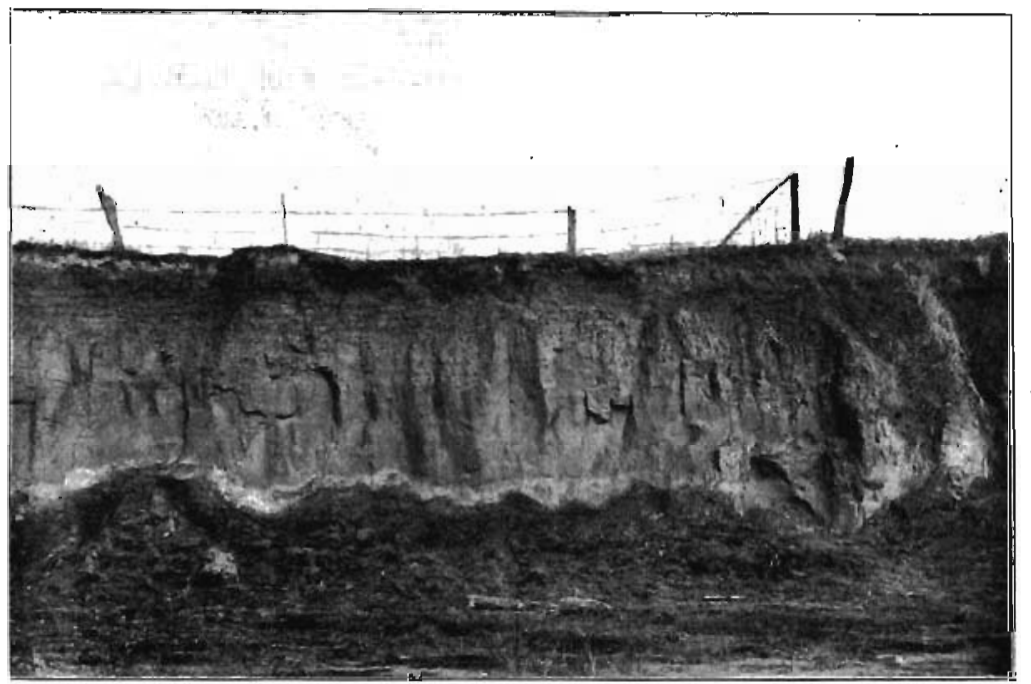

Fig. 30. Exposure of fossiliferous looss in the clay pit of Mr. Bentley, abcut 18 feet in deptl. The view shows the tendancy of this material to stand in vertical walls in excavations. A slightly lamina ed structure is present near the top.

fifty times as great as that of the Iowan, I should be compelled to acknowledge that the estimate is very conservative." All of the facts that are presented in Tama county relative to the age

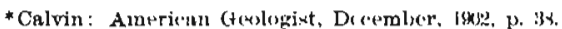


of the Iowan and the Kansan till would support the former of the comparisons given above.

Loess.-The general relation of the loess to the Iowan and the Kansan drift sheets in l'ama county is consistent with its distribution over the greater portion of Central Iowa near the margin of the Iowan drift plain. Loess forms a mantle at the surface over all of the Kansan area and covers with a thin sheet the most of the southern portions of the Iowan drift. Immediately adjacent to the Iowan border the deposits are deep. The materials here are largely composed of sand although the occurrence of beds of the finer loess clay is not infrequent. Over all of the other loess covered areas the deposit is a very fine-grained, yellow colored silt containing, no sand or pebbles and covering alike the summits, slopes and valleys. At numerous points the beds of loess attain a depth of fifteen to twenty-five feet. In many of these deeper deposits the shells of air-breathing univalves are abundant throughout the entire depth. In such beds the loess is usually quite calcareous. The segregation of the lime in the form of small nodules or concretions, loess-kindchen, along a line six to eight feet below the surface, occurs in a loess exposure near Tama in the southern part of section 25 of Tama township. These concretions are usually irregular in shape, two or three inches long and about one inch in diameter of cross section. They are generally impure, containing much clay material.

Even the deeper deposits of loess seldom present anything resembling lines of stratification, and when lamination planes are present they are such as might readily be formed in the deposit of wind blown materials.

All of the features connected with the deposit of loess in Tama county are such as might be developed through the agency of the wind. The presence of the fragile yet unbroken shells of land mollusks distributed through the entire thickness of the beds would indicate that each portion of the deposit had successively been a surface and that the shells were slowly buried by the accumulation of the materials after the animals that inhabited them had died. The fact that the loess mantle does not tend to level up the surface but duplicates the inequalities of the underlying drift would strongly suggest that it was laid down by the wind. 
The absence of usual stratification planes would be at variance with what would be expected to result from the sorting action of water if the materials were laid down by that agenoy.

Deposits of fine-grained, lress-like beds are forming at the present time wherever dust-laden winds have their velocity checked and especially where a carpet of grass or other vegetation covers the surface in such places so as to retain the dust that falls upon it.

Even the deeper beds adjacent to the Iowan border may possibly have been deposited by the same agent. Professor Calvin has shown that the materials of the loess of central and southern Iowa were probably derived from the finer constituents of the Iowan drift. The evidences which point to this source of the luess are its color and composition, its geographical relation to the Iowan border, and its superposition sometimes on the oxidized surface of the Kansan till and sometimes on the Iowan.* It would seem that the conditions during the time the Iowan ice prevailed would be exceptionally favorable for strong northerly and westerly winds whose sweep over the surface of the ice sheet would be unobstructed by great inequalities of surface or by the presence of forest areas. Then, too, the finer loose materials that were liberated as the general surface of the ice wasted by melting would be in prime condition to be gathered up and swept along by the winds. Much of these materials would probably be laid down around the margin of the ice, but some of the finer partions might readily be carried far beyond the border of the ice sheet. It would seem probable, too, that immediately adjacent to the Iowan border the waters from the melting ice would wash some of the sand and finer portions of the drift over the ice margin. However, the presence of occasional hills of loess, rich in fossils and the general absence of stratification planes in the deposits of sand along the moraine would indicate that even in the deposition of these materials the wind may have had a share.

Post-glacial Deposits.-Deposits of the Pleistocene later than those of the glacial series are found at numerous points over the county. An accumulation of peat occurs near the southeast corner of section 24 of Toledo township. This bog was formed by

*Calrin: Iowa Geol. Surr, Vol. VII. p. 89. 
the deposits at the margin of the Toledo labe of Iowan drift. It originally covered an area seyeral square rods in extent. A thin stratum of peaty substance can be traced for some distance in the bank of a stream that has since drained this old marsh. It is covered by a few inches of soil that has washed down from the bordering hills. The peat bed is not of sufficient thickness to be of commercial value, but it is of interest as recording here a condition of things that has since passed away. It is said that when some weeds were being burned from this field in the autumn come years ago, the peat caught fire and continned to burn for several weeks.

The channels of all of the larger streams of the county are bordered by a wide belt of alluvium. Excavations in the flood plain of the Iowa river show about four feet of dark colored, finegrained soil at the top, below which is a bed, twenty to thirtythree feet in thickness, which is composed of yellow clay, sand and gravel. This bed overlies the bowlder clay of the Kansan drift.

These deposits record a long interval after the Kansan drift was laid down in which the land stood higher than at present. During this period a wide valley was carved into the Kansan drift at least thirty feet deeper than the bed of the present river. The age of the sand and gravel deposit is not definitely known. It seems probable that the cutting was accomplished previous to the lowan ice invasion, and that the subsidence which is thought to lave attended the Iowan stage of glaciation resulted in the partial filling of the old pre-Iowan valley.

The same history is recorded in the valleys of all of the larger creeks of thle county. These all flow in wide channels which are covered with deep deposits of alluvium. The broad bottom of the Iowa river in Tama: county has an extent of almost one hundred square miles; while the flood plains of the creeks of the area would aggregate nearly as much more. These give to the county a large proportion of rich alluvial land. 


\section{Unconformities.}

After the sediments which constitute the rocks of the Kinderhook stage were laid down, an upward movement of the earth's crust carried this portion of the state above the sea. During all of the remainder of the Lower Carboniferous epoch this was a land surface, subjected to erosion. The Upper Carboniferous epoch was initiated by a downward oscillation of the crust that permitted the sandstone of the Des Moines stage to be deposited unconformably over the eroded surface of the Kinderhook strata.

The elevation which brought to a close the deposit of the Des Moines sandstones was collowed by an exceedingly long interval during which the area that now comprises Tama county was a land surface. It was probably toward the latter part of this intorval that the deep preglacial valleys above described were carved into the strata of the Carboniferous system. The earliest ice sheet spread its mantle of drift unconformably over this preglacial surface and the materials of each successive ice sheet were left unconformably over the eroded surface of the preceding.

\section{Preglacial Surface.}

From a study of the well sections and the rock exposures of the area, it will be seen that the surface of the indurated rocks, before it was covered by the mantle of till, presented greater inequalities than occur over the area at the present time. The table of elevations shows that the maximum known difference in altitude between even the most remote points within the county is only 267 feet; while the difference in elevation between adjacent points, as valleys and uplands, scarcely ever exceeds eighty or ninety feet. The record of a well on the farm of W. B. Mitche!! in Otter Creek township shows that the indurated rocks at that point are buried beneath 370 feet of superficial materials, while less than fifteen miles to the westward the indurated rock ledges cutcrop in the bluffs to the top of the hills. The preglacial relief at points not more than a dozen miles apart was 100 feet greater than the present maximum difference in altitude of points separated by the entire length of the county.

There is evidence that the bed of the old river valley whieh passes beneath the town of Vining and on to Belle Plaine is at 
least fifty feet deeper where it leaves the county than at the point in Otter Creek township where it was reached by the Mitchell well.

There is no doubt that the preglacial surface of Tama county was carved by the agents of erosion into deep wide valleys which were bordered by precipitous bluffs three to four hundred feet in height. This ancient topography must have presented features which resembled in many respects those of the driftless area at the present time. The leveling mantle of drift that was left by the successive ice sheets filled up these deep gorges and ravines so that the tops of the ancient hills are now but rarely seen.

Soils.

The soils of this favored area will always constitute the greatest source of wealth to the people of Tama county. The type of soil that occurs over the lowan drift plain is the most distinctive and probably the most fertile of any in the county. It is deep and black, rich in carbonaceous material and contains an abundance of mineral matter in such compounds as can readily be utilized by growing plants. The surface over this area is fairly well drained, yet the slopes are not so steep that the soil becomes rapidly impaverished by the washing, effects of lior

rain storms. There is no waste land on the farms, every square foot of which can be put under the plow. Over Tama county the lowan ice did not leave so many bowlders as it did over some other portions of the Iowan plain, hence the farmers here enjoy all of the advantages of the Iowan drift soil without the disadvantages that are present over the more thickly bowlder strewn areas. The handsome, well kept homes and the large commodious barns which characterize the farms over the lowan plain attest the great productiveness of this recent soil.

Another type of soil is found over the loess covered Kansan drift portion of the county. The Kansan surface in Tama county is thoroughly drained. The soil is loose and porous, easily tilled and never becomes water clogged. Where the land is not too rolling this soil is dark-colored, rich in organic matter and fairly productive. On the steeper slopes and over the more or less sandy ridges which border the Iowan plain the more desirable 
constituents of the soil are constantly removed by erosion so that the materials that contribute to the food of plants are not allowed to accumulate at the surface. When the earliest settlers came to Iowa they found this area covered with heavy timber. A few of the primeval trees may still be seen, surviving remnants of the splendid forests which at one time mantled these hills and valleys. The presence of a forest over the steeper slopes rrevented the wasting of the soil through rapid erosion and preserved as the fertile leaf-mould the products of plant decay that were formed upon the surface. With the destruction of the forests, however, the chief conservator of soil fertility over these slopes disappeared. When subjected to constant cultivation they yield but meagre returns for the labor and expense involved in the production of the orop. The original forests should never have been removed from these areas, but where this has been done if the surface is allowed to become grass covered and the land devoted to purposes of pasturage the strength of the soil can be retained and the owner of the land will be assured of a fair remuneration for all the labor which he expends upon it.

A third type of soil occurs over the flood plains of the principal streams of the county. This alluvium is usually underlain by a bed of sand and gravel which gives it thorough underdrainage. It is deep and rich and mellow, containing the cream of the soil removed from the hills bordering the channel and from the slopes which are drained by the tributary streams. Where not too low so as to be in danger of inundation, and where there is not too lairge a proportion of sand present, this alluvium is a very productive soil ranking second to none in ease of cultivation and general fertility.

\section{ECONOMIC PRODUCTS.}

Tama county is pre-eminently an agricultural district. The products, like the quality of her soils, are rich and varied. An abundant yieldi of corn and oats and grass never fails to reward richly the intelligent tiller of the land. The agricultural possibilities of Tama county are not yet reached and it is in that direction that the people of this fertile area must largely look for the basis of their prosperity and progress. 


\section{Building Stone.}

The total value of the output of building stone in Tama county for the year 1901 was $\$ 325$. * The stone suitable for building purposes comes from the Kinderhook stage of the Mississippian series. As described above, it is limited to a small area in the middle western portion of the county. Of these rocks the beds that have been used embrace the oolitic limestone and the arenaceo-magnesian beds which immediately overlie them. The oölite is a weak stone crumbling rapidly when exposed to the air. When polished it presents a pleasing appearance and if used in places where it will be protected from the weather it proves a very satisfactory stone. These oölite layers were aspecially desired for the making of lime in the days when each locality was dependent upon its own resources for building materials. There is but little of this stone used at the present for any purpose. When the importance of good roads is better appreciated and permanent road beds came to be built over the area, this oolitic limestone will be a valuable deposit, easily accessible and producing good results when used for road making.

Samples of the oölite from Montour were tested by Mr. Logan Waller Page of the Road Material Laboratory connected with the U. S. Department of Agriculture. The results of the test are given below:

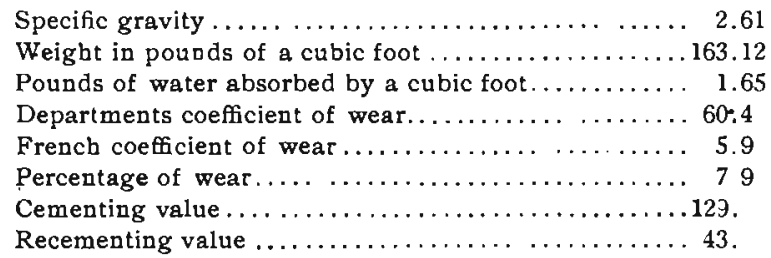

With regard to the use of this material in the building of roars: Mr. Page says, "Although this rook has a low coefficient of wear, its cementing value is so high that excellent results should be expected on light traffic roads."

The magnesian layers of the bed overlying the oölite furnish a desirable quaility of stone for rough foundation purposes. The material becomes harder after it has been taken from the ledge,

* Beyer: Iowa Geol. Surv., Vol. XII, p. 52. 
the layers are of such thickness as to make them easily worked and the supply is almost inexhaustible over the very limited area in which it occurs.

The demand is local, as the quarries at LeGrand are more accessible to the railroad, making the facilities for shipping stone much better there than at any point within Tama county. Practically all of the stone produced in the county comes from these arenaceo-magnesian layers overlying the oolite. Its value for use as road material may be judged from the results of tests made upon stone from these layers at the Butlerville quarry.

The report of Mr. Page upon this stone is as follows:

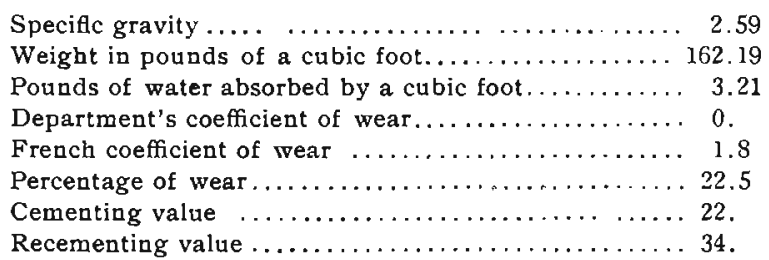

Relative to the above Mr. Page remarks: "This rock has too low a resistance to wear to warrant its use in macadamizing a road; but it has the peculiar property of recementing with in- creased strength and ought to make a good surfacing material." While in Tama county there are no deposits of gravel, which probably furnish the most desirable product for road making, yet there are materials suitable for that purpose in abundant quantities and close at hand. The oölite bed and the hard limestone layers which immediately overlie the aranaceo-magnesian bed in Tama county, and which are developed in greater thickness at exposures just across the border in Marshall, would, when crushed, make a good macadam. For surfacing material the beds that overlie the oölite would furnish a superior product in quantities almost unlimited.

\section{Lime.}

A number of years ago lime was burned on quite a large scale at Butlerville and at Montour. The beds of oolite were especially desired for that purpose. This limestone yields as good a quality of lime as can be made from the pure calcium carbonate and the materials for such a product occur at the above points in great İ̃ Q Rep 
abundance. However, the lime made from dolomite is superior in value to the best that can be produced from the lime carbonate in that it does not yield so readily to the action of the atmosphere. It can be kept longer without injury and it sets into a harder and more durable plaster or mortar. The magnesian layers, as a general rule, contain too large a proportion of sand to produce the best results in lime making.

Sand.

Sand suitable for building purpases occurs at a number of places in Tama county. Large quantities are annually taken from the sand flats along the bed of the Iowa river. The sand hills of the Iowan moraine furnish unlimited quantities in the central portion of the county. Some of the more incoherent layers of the Kinderhook sandstone would furnish serviceable material for plaster if abundant deposits easier of access were not available.

\section{Clay.}

According to the statistics compiled by Professor Beyer on the Mineral Products of Iowa, the value of the clay products manufactured in Tama county for the year 1901 aggregated $\$ 63,500 .{ }^{*}$. Brick and tile are the only clay products at present made within the area The raw material is furnished mostly by the deposits of loess and alluvium. Factories are supported at various points over the county.

Toledo. $-\Lambda$ brick and tile factory owned and operated by John Wild and son is located just west of town near the Chicago and Northwestern depot. The plant includes two drying sheds, $4 \$ \times 150$ feet and $20 \times 150$ feet respectively, with drying space of 12,600 square feet. It is equipped with a thirty horse power Erie engine, a J. D. Fate brick machine, with a capacity of 25,000 brick per day, and a tile machine of the same make with a daily capacity of 10,000 three-inch tile. Various sizes of tile are manufactured, ranging from 3 to 8 inches $\mathrm{n}$ diameter. There are two up-draft kilns with a capacity of 180,000 brick, and one downdraft with a capacity of about 55,000. The plant is in operation

- Beyer: Iowa Geol. Surv., Vol. XII. p. 49. 
about nine months of the year, during the greater part of which time ten men are employed. The most of the brick and tile are sold to farmers and builders within a radius of eight or ten miles. 'The total value of the output of brick per year is about $\$ 7,000$, while the value of the tile production is about one-fourth of that amount. The clay used at this place is a loess alluvium about eight feet in depth which occurs along the valley of Deer creek.

Tama.-About one mile east of Tama, in the southwest quarter of section 25 of Tama township, there is a brickyard owned and operated by C. B. Bentley and son. This factory is equipped with a forty horse power engine and a Brewer tile and brick machine with a capacity of 25,000 to 30,000 brick per day. There are two up-draft kilns, a drying shed $80 \times 100$ feet and a machine building 40x60 feet. This plant is in operation about six months of the year. The value of the brick output for the year is $\$ 6,000$

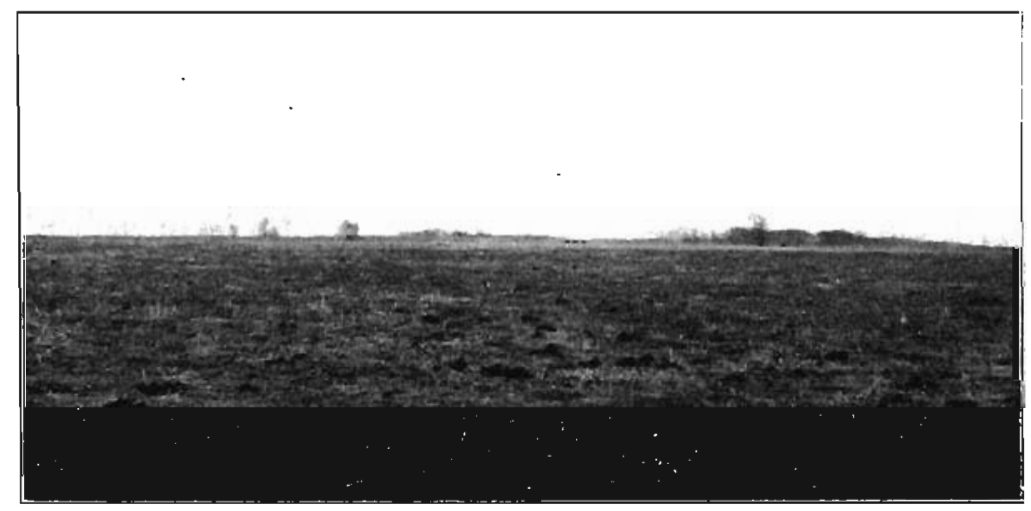

Fig. 31. Typical view of the level Iowan plain in the northern part of Tama connty.

to $\$ 7,000$. The material is mostly sold in Tama and the surrounding district within a radius of a few miles. The olay pit is in a bed of fossiliferous loess about twenty feet in depth which occurs on the north bank of the Iowa river.

Gladbrook.-Two large plants for the manufacture of clay products are operated at Gladbrook. The works of the Gladbrook Pressed Brick and Tile Company are located about one mile west 
of town on the Chicago and Great Western Railroad. The factory includes a press room $30 \times 40$ feet, clay shed $80 \times 120$ feet, one drying room: $24 \times 84$ feet, two stories provided with steam heat (and furnishing 20,160 square feet of tile space), another $20 \times 80$ feet without steam, with drying space of 12,800 square feet, an engine room $40 \times 50$ feet and a tile room $20 \times 24$ feet in size. There are two Eudaly kilns $14 \times 56$ feet, each of which has a capacity of 100,000 brick, and two round kilns 26 feet in diameter with a brick capacity of 65,000 . The plant is equipped with two slide valve engines, forty-five and fifteen horse-power respectively, and a fifty horse-power tubular boiler, an Andrus dry press, a revolving: 'disintegrator, and a Brewer's tile machine. 'The daily hrick capacity is 18,000 and that of tile three inches in diameter is 8.000 to 10,000 . Different sizes of tile are made running all the way from three to twelve inches in diameter. The works employ about seventeen men and are in operation ten months of the year. The ware burns to a deepr cherry red color and is of superior quality. The value of the annual output of briok is $\$ 9,750$ and of tile is $\$ 7,000$. The products are mostly shipped to various points in Iowa.

The vard of Gelham Brothers Brick Company is about threefourths of a mile west of Gladbrook, along the tracks of the Chicago and Great Western Railroad. This plant embraces a press and engine room, clay shed and brick and kiln shed; an eighty lorse power Stanwood, Houslen and Gamble engine and boiler, a Boyd dry press and an Albrecht disintegrator. Their daily capacity of brick is about 18,000. Sixteen men are employed during about ten months of the year. The value of the annual product is about $\$ 18,750$. The principal market for the brick is found at home and in neighboring towns at no great distance away.

Traer.-The plant of the Traer Brick and Tile Company is situated a short distance north of the depot on the Chicago and Northwestern Railroad. It is owned and operated by Messrs. Budlong and Gates. The buildings consist of an engine room and two large drying sheds, which latter have a capacity of 200 ,0.j0 brick at one time. No artificial heat is used in drying the wares. The equipment of the factory includes one fifty horse 
power Atlas engine and a J. D. Fate stiff mud machine which by ohanging dies and table is used for either brick or tile. There are two round down draft kilns with a separate capacity of 60 ,000 brick. The standlard sizes of tile, three, four, six, eight and ten inches in diameter, are produced. The plant employs about a dozen men during nine months of the year. The total value of the yearly output of tile is $\$ 3,000$ and of brick $\$ 7,000$. Their market. is chiefly in and about Traer.

\section{Water Supply.}

The Iowa river furnishes an abundant supply of water to thearea through which it flows. The larger ereeks all head in the marshy sloughs of the Iowan drift plane. These springs dole out to the surface streans a supply of water, clear and constant, which continues to flow throughout the year. Abundant water is furnished by shallow wells from the porous beds of the Pleistocene in almost every part of the county. Flowing wells are obtained by penetrating the gravel bed of Aftonian age which underlies the Kansan drift along a deep preglacial valley in the southern portion of the area. Sometimes the water supply seems 10 corre from the indurated rocks adjacent to this bed of gravels. It. seems likely, however, that even in such places this porous deposit is the real source of the accumulation of the water which probably fell upon the surface some miles to the northward.

\section{ACKNOWLEDGMENTS.}

The writer is glad for this opportunity to acknowledge the lindness of many persons who rendered assistance during the prosecution of the work set forth in the preceding pages. Thanks are especially due to the director of the Survey, Professor Calvin, for counsel and helr; to Mr. William Westfall of Toledo, and $\mathrm{Mr}$. Clyde Stauffer of Gladbrook for assistance in the collection of data, and to niany others whose interest in the work was unfailing, and whose service was limited only by their opportunity. To all of the above the author wishes to express his. high appreciation of their service and tender his sincere thanks. 


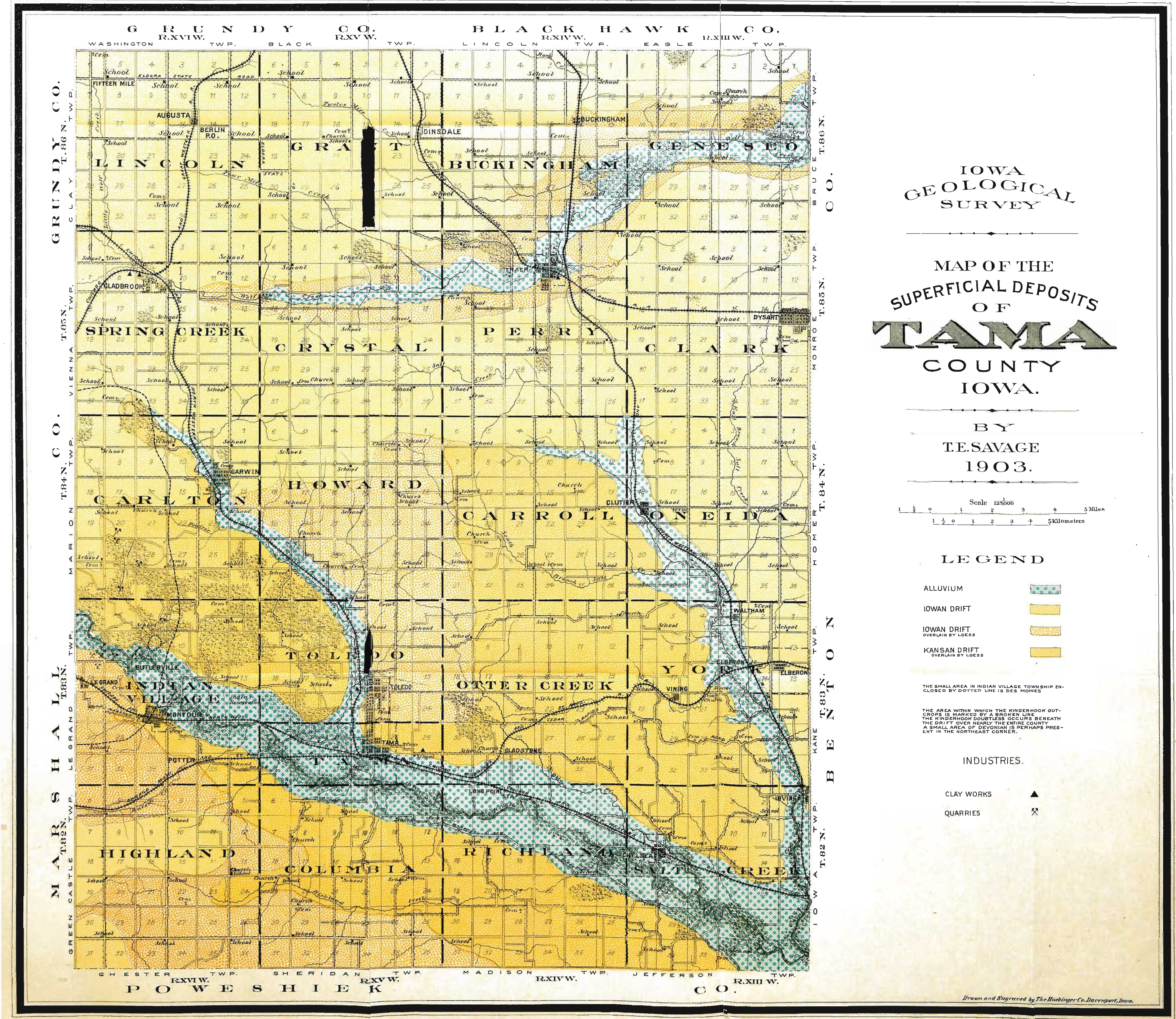

